\title{
Multiple driving factors explain spatial and temporal variability in coral calcification rates on the Bermuda platform
}

\author{
A. Venti $\cdot$ A. Andersson $\cdot$ C. Langdon
}

Received: 8 February 2014/ Accepted: 11 July 2014/Published online: 22 July 2014

(c) The Author(s) 2014. This article is published with open access at Springerlink.com

\begin{abstract}
Experimental studies have shown that coral calcification rates are dependent on light, nutrients, food availability, temperature, and seawater aragonite saturation $\left(\Omega_{\text {arag }}\right)$, but the relative importance of each parameter in natural settings remains uncertain. In this study, we applied Calcein fluorescent dyes as time indicators within the skeleton of coral colonies ( $n=3$ ) of Porites astreoides and Diploria strigosa at three study sites distributed across the northern Bermuda coral reef platform. We evaluated the correlation between seasonal average growth rates based on coral density and extension rates with average temperature, light, and seawater $\Omega_{\text {arag }}$ in an effort to decipher the relative importance of each parameter. The results show significant seasonal differences among coral calcification rates ranging from summer maximums of $243 \pm 58$ and $274 \pm 57 \mathrm{mmol} \mathrm{CaCO}_{3} \mathrm{~m}^{-2} \mathrm{~d}^{-1}$ to winter minimums of $135 \pm 39$ and $101 \pm 34 \mathrm{mmol} \mathrm{CaCO}_{3} \mathrm{~m}^{-2} \mathrm{~d}^{-1}$ for $P$. astreoides and D. strigosa, respectively. We also placed small coral colonies $(n=10)$ in transparent chambers and measured the instantaneous rate of calcification under light and dark treatments at the same study sites. The results
\end{abstract}

Communicated by Biology Editor Dr. Simon Davy

\section{A. Venti $(\bowtie) \cdot$ C. Langdon}

Rosenstiel School of Marine and Atmospheric Sciences,

University of Miami, 4600 Rickenbacker CSWY, Miami,

FL 33149, USA

e-mail: aventi@rsmas.miami.edu

C. Langdon

e-mail: clangdon@rsmas.miami.edu

\section{A. Andersson}

Scripps Institution of Oceanography, University of California San Diego, 9500 Gilman Dr., La Jolla, CA 92093-0202, USA e-mail: aandersson@ucsd.edu showed that the skeletal growth of D. strigosa and $P$. astreoides, whether hourly or seasonal, was highly sensitive to $\Omega_{\text {arag. }}$. We believe this high sensitivity, however, is misleading, due to covariance between light and $\Omega_{\text {arag, }}$, with the former being the strongest driver of calcification variability. For the seasonal data, we assessed the impact that the observed seasonal differences in temperature $\left(4.0^{\circ} \mathrm{C}\right)$, light (5.1 mol photons $\mathrm{m}^{-2} \mathrm{~d}^{-1}$ ), and $\Omega_{\text {arag }}(0.16$ units) would have on coral growth rates based on established relationships derived from laboratory studies and found that they could account for approximately 44,52 , and $5 \%$, respectively, of the observed seasonal change of $81 \pm 14 \mathrm{mmol} \mathrm{CaCO}_{3} \mathrm{~m}^{-2} \mathrm{~d}^{-1}$. Using short-term light and dark incubations, we show how the covariance of light and $\Omega_{\text {arag }}$ can lead to the false conclusion that calcification is more sensitive to $\Omega_{\text {arag }}$ than it really is.

Keywords Coral calcification - Ocean acidification . Bermuda $\cdot$ Aragonite saturation state

\section{Introduction}

The negative effects of ocean acidification (OA) on coral calcification rates and net ecosystem calcification (NEC) rates have been well documented with a strong correlation observed between seawater aragonite saturation state $\left(\Omega_{\text {arag }}\right)$ and rates of calcification (e.g., Langdon and Atkinson 2005; Hoegh-Guldberg et al. 2007; Andersson and Mackenzie 2011). These results, however, are heavily drawn from controlled aquarium and mesocosm studies, which isolate OA by manipulating seawater inorganic carbon chemistry while keeping other parameters such as light, temperature, salinity, nutrients, and flow rates constant. Previous research has shown that coral calcification 
rates are also a direct function of these parameters, as well as the seawater inorganic carbon chemistry (e.g., Chalker and Taylor 1975; Koop et al. 2001; Mass et al. 2010). In situ studies, which in general do not control these parameters, are limited in their ability to evaluate the relative importance of the controlling factors on the rate of calcification, but can be helpful in assessing the combined impact of these parameters.

Seasonal differences in light, temperature, and seawater inorganic carbon chemistry, including seawater $\mathrm{pH}$ and $\Omega_{\text {arag }}$, are more pronounced in higher latitude reefs, such as the Bermuda coral reef. For example, seasonal differences in $\Omega_{\text {arag }}$ of up to 1.2 units have been recorded on the northern reef platform of Bermuda (Bates et al. 2010), while lower latitude reefs such as Davies Reef (Great Barrier Reef, GBR) exhibit smaller seasonal ranges of 0.15 (Albright et al. 2013). On diurnal timescales, the same is true for shallow reef systems. For example, large diurnal fluctuations in $\Omega_{\mathrm{arag}}$, from 1.5 to 6 units, have been observed on Lady Eliot Island (GBR) where reef waters are typically less than $1 \mathrm{~m}$ deep (Shaw et al. 2012). These types of environments provide natural laboratories to investigate rates of calcification under a broad range of seawater $\Omega_{\text {arag. }}$.

Though field data are limited, correlation between calcification rates and temporal variability in seawater temperature, light, and $\Omega_{\text {arag }}$ have been observed on coral reef ecosystems at diurnal (e.g., Suzuki et al. 1995; Yates and Halley 2003, 2006; Price et al. 2012) and seasonal (e.g., Silverman et al. 2007; Manzello et al. 2008; Bates et al. 2010; Shamberger et al. 2011; Albright et al. 2013) timescales. However, the interdependence of these parameters makes deciphering the relative importance and the principle driving mechanism(s) difficult. For example, increased light levels cause warmer temperatures, which also directly affect $\Omega_{\text {arag }}$ (higher temperature increases $\Omega_{\text {arag }}$ by decreasing aragonite solubility). Some studies have found a significant relationship between coral calcification and temperature (e.g., Marshall and Clode 2004; Reynaud et al. 2004; Silverman et al. 2007), while others have not (e.g., Shaw et al. 2012). To some extent, a positive relationship between temperature and calcification rates may be due to the effect of temperature on seawater $\Omega_{\mathrm{arag}}$ (Silverman et al. 2007; Shaw et al. 2012), but this effect is relatively small $\left(0.03\right.$ units per $\left.2{ }^{\circ} \mathrm{C}\right)$.

Conversely, the concept of light-enhanced calcification has been well established (Kawaguti and Sakumoto 1948; Gordeau 1959; Goreau and Goreau 1959) and can increase coral calcification rates by three to ten times compared with rates in the dark (Gattuso et al. 1999; Moya et al. 2006). Light availability may also determine the susceptibility of reef building corals to pressures from OA. Increased gross photosynthesis under high light conditions has been shown to effectively enhance calcification in Aiphanes horrida and Parapercis cylindrica, even under high $\mathrm{CO}_{2}$ treatments (Suggett et al. 2012). At seasonal timescales, the net reef community metabolism may also affect the reef's susceptibility to pressures from OA. Strong net autotrophy from benthic components of the reef system may enhance $\Omega_{\text {arag }}$ due to photosynthetic uptake of $\mathrm{CO}_{2}$, while $\Omega_{\text {arag }}$ may be suppressed by the release of $\mathrm{CO}_{2}$ from reef metabolism during periods of strong net heterotrophy, as proposed by the coral reef ecosystem feedback (CREF) hypothesis (Bates et al. 2010).

The present study measured the calcification rates of two scleractinian coral species (Diploria strigosa and Porites astreoides) at three sites across the Bermuda coral reef platform at seasonal (winter/summer) and hourly (light/ dark) timescales to better understand how coral calcification rates vary across natural temporal and spatial differences in light, temperature, and seawater $\Omega_{\text {arag }}$. Seasonal Calcein staining was conducted in March 2010, September 2010, and March 2011, and colonies were cored in September 2011, while hourly incubations were conducted in September 2010 and 2011. Though natural temporal and spatial differences in nutrients are also likely, these data were beyond the scope of the present study. We compare seasonal coral calcification rates from Bermuda with calcification rates measured by similar methods in other reef environments and discuss the relative importance of seawater carbonate chemistry (specifically $\Omega_{\text {arag }}$ ) on coral calcification rates at hourly and seasonal timescales.

\section{Materials and methods}

\section{Study site}

Bermuda offers a unique environment to study the effects of $\mathrm{OA}$ on coral calcification rates. Bermuda lies on the northern limit of tropical coral reefs ecosystems and thus experiences threshold oceanic environmental and chemical conditions with respect to temperature and light, and possibly $\Omega_{\text {arag }}$ and $\mathrm{pH}$, for supporting this ecosystem. It has been hypothesized that Bermuda is likely to be affected by OA sooner than lower latitude reefs, making Bermuda an important location to study the effects of seawater inorganic carbon chemistry on coral calcification rates (Kleypas et al. 1999, 2001; Bates et al. 2010). Bermuda is also relatively spared from major human influences, such as pollution, run-off, overfishing, and dredging common to many US and Caribbean reefs and has been protected relatively successfully by local legislation. Therefore, observed long-term changes in coral calcification rates are likely to reflect large-scale pressures from global climate change (GCC) and OA rather than local factors. 
Rim reef waters are rapidly flushed by offshore water (1-2 d), while longer residence times are found closer to shore (10-15 d; Venti et al. 2012). Consequently, the potential for a spatial gradient in carbon chemistry across the Bermuda reef platform seems likely. However, Andersson et al. (2013) have shown that despite a strong seasonal and spatial signal in the distributions of total alkalinity (TA) and dissolved inorganic carbon (DIC), only relatively small spatial gradients in $\mathrm{pH}$ and $\Omega_{\text {arag }}$ are observed across the platform due to the nearly proportional changes in DIC and TA owing to net reef metabolism (i.e., net ecosystem production, $\mathrm{NEP}=$ primary production - autotrophic and heterotrophic respiration; net ecosystem calcification, $\quad \mathrm{NEC}=$ calcification $\mathrm{CaCO}_{3}$ dissolution; Andersson and Gledhill 2013). Nevertheless, in an effort to capture the maximum range of environmental and chemical conditions experienced across the platform, three spatially separated sites were selected for the present study: East of North Rocks (NR; $32.473247^{\circ} \mathrm{N}, 6^{6} .74572^{\circ} \mathrm{W}$ ), Whalebone Bay (WB; $32.364516^{\circ} \mathrm{N}, \quad 64.71573^{\circ} \mathrm{W}$ ), and Buoy 29 (B29; $32.32203^{\circ} \mathrm{N}, 64.811718^{\circ} \mathrm{W}$; Fig. 1).
Seasonal coral calcification rates

Coral calcification rates $(G)$ can be defined as the product of the coral's vertical extension during a given time interval $(X)$ and its skeletal density $(\rho)$ (Chalker et al. 1985):

$X \mathrm{~cm} \mathrm{~d}^{-1} \cdot \rho \mathrm{gCaCO}_{3} \mathrm{~cm}^{-3}=G \mathrm{gCaCO}_{3} \mathrm{~cm}^{-2} \mathrm{~d}^{-1}$

In this study, we combined a calcein dye staining method, which has not been shown to negatively impact coral growth, to assess seasonal vertical extension with X-ray imaging analysis of coral core slices to quantify coral density and thus seasonal calcification rates.

Seasonal calcification rates were measured for a total of eighteen coral colonies, three $P$. astreoides and three $D$. strigosa at three study sites. The staining process consisted of loosely "tenting" tagged coral colonies with an impermeable plastic tarp secured to the base of the coral with bungee cords. Diluted calcein dye $\left(1 \mathrm{~g} \mathrm{~L}^{-1}\right.$ of sea water) was released under the tarp, which remained over the coral for $18-24 \mathrm{~h}$ before being removed. Despite longer than ideal tenting events, coral colonies did not exhibit any

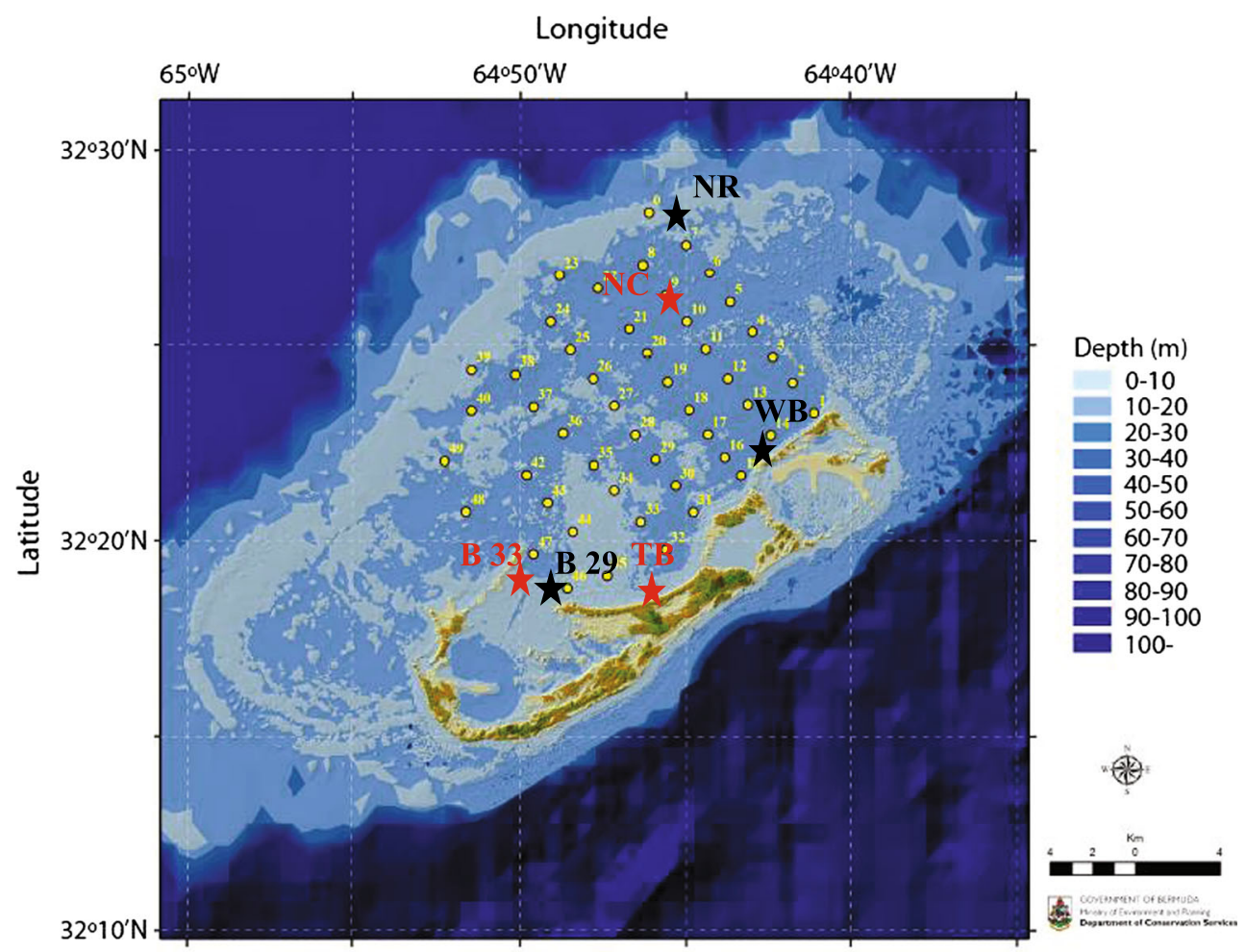

Fig. 1 Bermuda and the Bermuda reef platform. Black stars indicate three sites selected for the present study, North Rocks (NR), Whalebone Bay (WB), and Buoy 29 (B29). Yellow dots denote sampling stations for the surface water platform survey conducted in March (winter) and September (summer) 2012. Red stars indicate the location of monthly environmental data collected between March 2010 and September 2011 by the BEACON project: Buoy 33 (B33), North Channel (NC), and Tyne's Bay (TB). Map credit: M. Shailer, Dept. of Conservation Services, Government of Bermuda 
signs of stress (e.g., bleaching, paling) from being tented. Colonies were stained during seasonal sampling expeditions in March 2010, September 2011, and March 2011. In September 2011, stained corals were cored on SCUBA using a pneumatic hand drill attached with a diamond coring bit, capturing three complete growth periods: two periods from March to September, encompassing mostly "summer" months, and one period from September to March, designated as "winter" months. The distance between each seasonal calcein band, revealed by a fluorescent filter, represents the coral's vertical extension between sampling periods. Coral density was measured on coral cores sliced to a uniform thickness of $0.5 \mathrm{~cm}$ using $\mathrm{X}$-ray imaging analysis and Coral XDS software (Chalker et al. 1985; Helmle et al. 2002; http://www.nova.edu/ ocean/coralxds/index.html).

\section{Light/dark coral calcification rates}

Though well suited for seasonal timescales, the calcein staining method is not applicable for diurnal resolution. Instead, we conducted short-term incubation experiments using the alkalinity depletion method to determine hourly calcification rates in light and dark conditions. This method is based on the principle that seawater TA is depleted in a mol ratio of 2:1 for every mol $\mathrm{CaCO}_{3}$ deposited by the coral during the incubation period. This relationship is defined in Schneider and Erez (2006) as:

$G\left(\mu \mathrm{mol} \mathrm{CaCO}_{3} \mathrm{~cm}^{-2} \mathrm{~h}^{-1}\right)=\frac{(\Delta \mathrm{TA} / 2) \cdot\left(V_{\text {chamber }}-V_{\text {coral }}\right) \cdot \rho}{t \cdot \mathrm{SA}}$

where $\Delta \mathrm{TA}\left(\mu \mathrm{mol} \mathrm{kg}{ }^{-1}\right)$ is the change in total alkalinity during incubation, $V_{\text {chamber }}$ and $V_{\text {coral }}\left(\mathrm{m}^{3}\right)$ are the volumes of the chamber and displaced by the coral, respectively, $\rho$ $\left(\mathrm{kg} \mathrm{m}^{-2}\right)$ is the density of sea water, $t(\mathrm{~h})$ is the duration of the incubation, and SA $\left(\mathrm{m}^{2}\right)$ is the surface area of the coral nubbin.

In March 2010, ten coral "nubbins," five of each $P$. astreoides and D. strigosa, were collected at each site, epoxied onto PVC sleds and secured onto a platform at the site from which the corals were collected. The initial surface area of all corals was measured with calipers assuming simple geometric forms unique for each colony (i.e., half sphere, cone). In general, D. strigosa were classified as half sphere geometries, while $P$. astreoides were typically coneshaped, though each colony's geometry was assessed independently for surface area analysis. In September 2010, after corals had a chance to recover from the collection process, and again in September 2011, light and dark calcification rates were measured in situ by collecting water samples from $2-1$ incubation chambers after $\sim 1.5-\mathrm{h}$
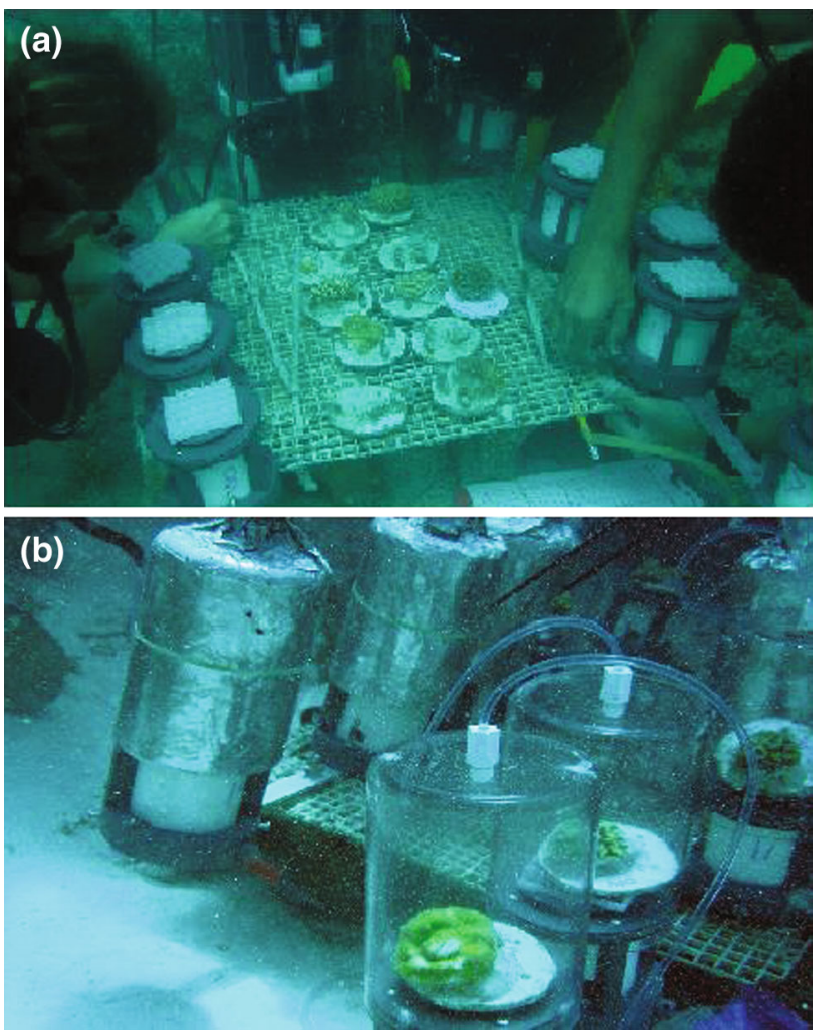

Fig. 2 Platforms used for a hourly incubation study and $\mathbf{b}$ hourly incubation analysis. Chambers in the background with the tin-foil represent dark incubations, and chambers in the foreground represent light incubations

incubation. All chambers were fitted with a battery-operated magnetic stirring bar to ensure sufficient water circulation within the chamber during the incubation process (Fig. 2). Dark incubations were achieved by covering chambers with aluminum foil. Water samples were collected from the water column above the platform at the start of incubations to quantify the initial conditions and also at the end from each chamber by syringe from a sampling hose secured with a clamp. Water samples from blank incubation chambers were used to correct for any net water column metabolism (i.e., to understand the change in TA over time in the water column). Incubations were typically conducted around noon, though exact starting times varied between stations and sampling year. Dark incubations were conducted first, after which aluminum foil was removed and chambers were flushed with fresh water before starting the light incubations, roughly $2.5 \mathrm{~h}$ after the dark incubation.

\section{Platform surveys}

To assess the spatial variability in seawater inorganic carbon chemistry across the Bermuda coral reef platform within the scope of this study, we conducted two platform- 
wide surveys in March and September 2012 (Fig. 1). At each of 50 stations, surface seawater measurements of temperature, salinity, and dissolved oxygen were taken with a yellow springs instrument (YSI) analyzer and water samples were collected for TA and DIC analysis.

\section{Sample analyses}

Seawater samples for DIC and TA from the spatial surveys were collected in thrice rinsed 250-ml PETG bottles. Samples from the in situ chamber experiments were drawn into four 50-cc plastic syringes by divers and transferred through $0.45 \mu \mathrm{m}$ cellulose acetate filters to 250 -ml PETG bottles at the surface. A headspace of $\sim 1-2 \%$ of the sample volume was created to allow for water expansion, and $100 \mu \mathrm{l}$ of saturated $\mathrm{HgCl}_{2}$ was added to stop biological activity. All samples were analyzed within six weeks of collection. Dissolved inorganic carbon was measured by an acidification/gas extraction technique using an Apollo Scitech AS-C3 Total Dissolved Inorganic Carbon Analyzer. In this technique, $0.75 \mathrm{ml}$ sample maintained at $25{ }^{\circ} \mathrm{C}$ is drawn up into a syringe pump, mixed with $1 \mathrm{ml}$ of $10 \% \mathrm{H}_{3} \mathrm{PO}_{4}$ acid and injected into a gas stripping cell where UHP $\mathrm{N}_{2}$ gas carries the $\mathrm{CO}_{2}$ gas through a LICOR $7000 \mathrm{CO}_{2}$ Gas Analyzer. The LICOR integrates the absorbance versus time signal and yields a net result that is proportional to the total inorganic carbon content of the sample. Seawater-certified reference material (CRM's, prepared by A. Dickson, Scripps Institution of Oceanography) was analyzed at the beginning and end of each 15-20 sample run to ensure accuracy of the DIC measurements. Precision based on analysis of replicate offshore samples was $0.17 \%\left(\sim 3 \mu \mathrm{mol} \mathrm{kg}{ }^{-1}, n=17\right)$.

Total alkalinity was determined by potentiometric titration with $0.1 \mathrm{M} \mathrm{HCl}$. The second equivalence point was determined by iteratively fitting a modified Gran function (Hansson and Janger 1973) to the titration data using code originally written by D. Archer, University of Chicago. Certified reference materials were analyzed at the beginning and end of each set of 15 samples to ensure the accuracy of TA measurements. Precision based on analysis of replicate offshore samples was $0.19 \%\left(\sim 4 \mu \mathrm{mol} \mathrm{kg}{ }^{-1}\right.$, $n=17$ ). All CRMs, DIC, and TA samples were run in duplicate. Total alkalinity and DIC samples were filtered through $0.45 \mu \mathrm{m}$ cellulose acetate filters before analysis to remove any carbonate particulates that might be present in the sample. The $\mathrm{pCO}_{2}, \mathrm{pH}$ (total scale), and $\Omega_{\mathrm{arag}}$ were calculated as a function of the measured salinity, temperature, TA, and DIC using the program CO2SYS, dissociation constants for carbonate acid determined by Mehrbach et al. (1973) as refit by Dickson and Millero (1987), and the dissociation constant for boric acid determined by Dickson (1990).
Complementing environmental data

Though platform survey data were valuable in assessing spatial trends in carbon chemistry, it was limited in its temporal resolution. To assess the relationship between coral calcification over the 6-month growth periods of our three season study, we utilized monthly salinity, temperature, TA, and DIC data collected by BIOS' water quality monitoring program (WQMP) and the Bermuda Ocean Acidification and Coral Reef Investigation (BEACON) project from three sampling stations distributed across the Bermuda coral reef platform (Fig. 1). Though sampling sites were not exactly at the same location as our three study sites, similar environmental characteristics between north channel (NC) and NR, Tyne's Bay (TB) and WB, and Buoy 33 (B33) and B29, motivated the analysis of environmental data from the former sites with coral growth data from the later. What we lost in spatial resolution (i.e., these sampling sites were not exactly the same location as our three study sites) was compensated for by higher temporal resolution, as platform survey data from the present study was limited to $1 \mathrm{~d}$ during summer and winter. Light data were collected at the L. F. Wade Bermuda International Airport in St. George by BAS-Serco and the Bermuda Weather Service in 1-min intervals that were integrated over $24 \mathrm{~h}$ to yield daily PAR values for each day of the three 6-month sampling periods.

\section{Results}

Corals were stained at our three study sites, (NR, WB, and B29) in March 2010, September 2010, and March 2011, and cored in September 2011, marking three 6-month growth periods. The environmental characteristics of each of these growth periods, collected by the BEACON project, are reported below, followed by the corresponding growth data.

\section{Environmental conditions}

\section{March 2010-Sept 2010 (summer I)}

Monthly measurements from NC, TB, and B33 showed that surface water temperatures ranged from a minimum of $17.5^{\circ} \mathrm{C}$ in late March to a maximum of $29.5^{\circ} \mathrm{C}$ in late August, with an average temperature of $24.5{ }^{\circ} \mathrm{C}(\sigma=4.3$, $n=21$ ) for the first 6-month growth period (Fig. 3). Light levels ranged from $7.4 \mathrm{~mol} \mathrm{~m}^{-2} \mathrm{~d}^{-1}$ in late March to $66.5 \mathrm{~mol} \mathrm{~m}^{-2} \mathrm{~d}^{-1}$ in June, with an average of $47.3 \mathrm{~mol} \mathrm{~m}^{-2} \mathrm{~d}^{-1}\left(\sigma=12, n=280\right.$; Fig. 3). The $\Omega_{\mathrm{arag}}$ reached a minimum in April, with values of 3.35 and 3.36 for $\mathrm{TB}$ and $\mathrm{B} 33$, respectively (Fig. 3). At $\mathrm{NC}, \Omega_{\text {arag }}$ 

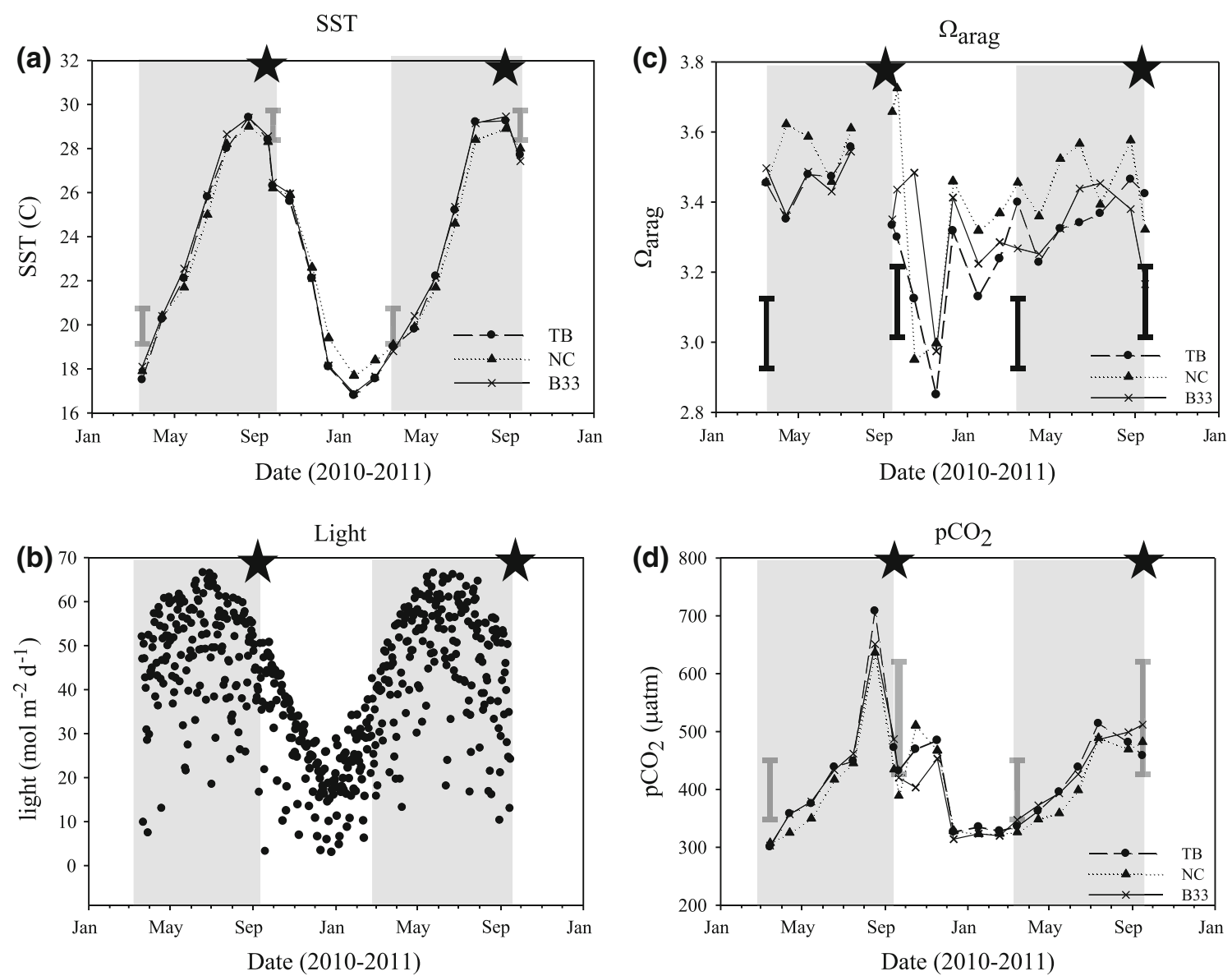

Fig. 3 Environmental data during the seasonal coral staining study. a SST, c $\Omega_{\text {arag }}$ and $\mathbf{d ~ p C O}{ }_{2}$ data came from monthly sampling by the BEACON project. b Light data came from the BAS-Serco and the Bermuda Weather Service. Light gray bars represent the two

reached a minimum of 3.57 in both March and mid-June. The maximum $\Omega_{\text {arag }}$ was observed at all three study sites in mid-July with values of $3.56,3.61$, and 3.54 , for TB, NC, and B33, respectively. The average $\Omega_{\text {arag }}$ during this period was $3.46(\sigma=0.07, n=5), 3.46(\sigma=0.07, n=5)$, and $3.55(\sigma=0.08, n=5)$, at $\mathrm{TB}, \mathrm{B} 33$, and $\mathrm{NC}$, respectively. Seawater $\mathrm{pCO}_{2}$, though not discussed in this paper, agrees with the $\Omega_{\text {arag }}$ results and is also shown in Fig. 3 for context. Though there were no significant differences in SST among the three study sites (1-way ANOVA, $\left.F_{(1,12)}=0.009, p=0.99\right)$, there was a significant difference in the $\Omega_{\text {arag }}$ among the three study sites (1-way ANOVA, $\left.F_{(1,12)}=4.43, p=0.03\right)$.

\section{September 2010-March 2011 (winter)}

Minimum temperatures reached $16.8^{\circ} \mathrm{C}$ in January and a maximum temperature of $26.3{ }^{\circ} \mathrm{C}$ in late September, with an average of $20.0{ }^{\circ} \mathrm{C}(\sigma=4, n=21)$ for the second 6-month growth period (Fig. 3). Though daily light values

"summer" periods; the white bar represents the "winter" sampling period. Stars indicate time of hourly incubation study. Dark gray bars represent the range of the parameter observed during the platform surveys in March and September 2012

varied from a minimum of $3 \mathrm{~mol} \mathrm{~m} \mathrm{~m}^{-2} \mathrm{~d}^{-1}$ to a maximum of $50.7 \mathrm{~mol} \mathrm{~m}^{-2} \mathrm{~d}^{-1}$ (Fig. 3), they were typically low, averaging $27.7 \mathrm{~mol} \mathrm{~m}^{-2} \mathrm{~d}^{-1}(\sigma=11.4, n=183)$. The $\Omega_{\text {arag }}$ was low with an average of $3.28(\sigma=0.25, n=6)$ at $\mathrm{NC}, 3.27(\sigma=0.048, n=6)$ at B33, and $3.22(\sigma=0.048$, $n=6)$ at TB (Table 1). Spatial differences were minimal with SST and $\Omega_{\text {arag, }}$, showing no significant differences among the three study sites (1-way ANOVA, $F_{(1,12)}=0.03, p=0.99$ for SST; 1-way ANOVA, $F_{(1,12)}=0.73, p=0.49$ for $\left.\Omega_{\mathrm{arag}}\right)$.

\section{March 2011-September 2011 (summer II)}

Sea surface temperature ranged from $18.8^{\circ} \mathrm{C}$ in March to a maximum of $29.5^{\circ} \mathrm{C}$ in late August, with an average SST of $24.6{ }^{\circ} \mathrm{C}(\sigma=4.1, n=6)$. Light levels ranged from 10.3 to $66.5 \mathrm{mmol} \mathrm{m}^{-2} \mathrm{~d}^{-1}$ with an average light level of $47.8 \mathrm{mmol} \mathrm{m}^{-2} \mathrm{~d}^{-1}(\sigma=12.7, n=281)$. The $\Omega_{\text {arag }}$ displayed different trends among study sites during the third 6-month growth period. At B33, the $\Omega_{\text {arag }}$ reached a 
minimum of 3.17 in September and a maximum of 3.45 in mid-July, with an average of $3.31(\sigma=0.13, n=7)$. At $\mathrm{TB}$, the $\Omega_{\text {arag }}$ reached a minimum of 3.23 in mid-April and a maximum of 3.46 in August. The average $\Omega_{\text {arag }}$ at TB was $3.33(\sigma=0.11, n=7)$. The $\Omega_{\text {arag }}$ at NC reached a minimum in September of 3.32, though the $\Omega_{\text {arag }}$ in April and July was also low (3.36 and 3.39, respectively). The maximum $\Omega_{\text {arag }}$ was observed in both June, 3.57 and again in August, 3.58 at NC. The average $\Omega_{\text {arag }}$ at NC during this period was $3.40(\sigma=0.19, n=7)$.

We found that the two summer (March-September) growth periods were not significantly different in terms of SST (ANOVA, $F_{(1,12)}=1.72, p=0.14$ ), $\Omega_{\text {arag }}$ (ANOVA, $F_{(1,12)}=0.40, p=0.126$ ), and light levels (ANOVA, $\left.F_{(1,361)}=0.39, p=0.46\right)$. This allowed us to pool environmental data from the two summer (March-September) sampling periods. The average SST, $\Omega_{\text {arag }}$, and light based on the pooled data for the two summer (March-September) periods were significantly greater than during the winter (September-March) period: 25.0 versus $21.0^{\circ} \mathrm{C}$ $\left(F_{(1,58)}=14.7, \quad p<0.0003\right), \quad 3.43 \quad$ versus 3.27 $\left(F_{(1,55)}=14.0, p<0.0004\right)$, and 47.9 versus $27.6 \mathrm{~mol}$ quanta $\mathrm{m}^{-2} \mathrm{~d}^{-1}\left(F_{(544)}=348, p<0.0001\right)$, respectively. We compared these differences in seasonal environmental data with results from our bi-seasonal coral growth experiment to assess the impact of these parameters on seasonal coral calcification rates in Bermuda.

Seasonal calcification rates

Calcification rates for D. strigosa were significantly higher during the summer (March-September) than the winter (September-March) period (218 \pm 10 vs. $128 \pm 14 \mathrm{mmol}$ $\mathrm{CaCO}_{3} \mathrm{~m}^{-2} \mathrm{~d}^{-1}$; 1-tailed $t$ test, $\left.t_{(11)}=5.3, p<0.0001\right) . P$. astreoides also calcified faster during the summer (MarchSeptember) than in the winter (September-March) period, but the difference was not significantly different $(267 \pm 45$ vs. $142 \pm 64$ mmol $\mathrm{CaCO}_{3} \mathrm{~m}^{-2} \mathrm{~d}^{-1} ;$ 1-tailed $t_{(7)}=1.6$, $p=0.076$; Table 2; Fig. 4).

The stained corals in this study experienced a wide range of environmental conditions during the 1.5-yr-long study (Fig. 3). The seasonal ranges in SST, light, and $\Omega_{\text {arag }}$ were fairly similar between the summer (March-September) and winter (September-March) periods. However, despite the broad overlap of conditions, the average SST, light, and $\Omega_{\text {arag }}$ during the two seasons were significantly different as were the seasonal coral growth rates (preceding section). A regression of seasonal coral calcification rates of the two coral species at the three locations with the seasonally averaged environmental conditions showed strong correlations with light $\left(r^{2}=0.8\right)$, SST $\left(r^{2}=0.79\right)$, and $\Omega_{\text {arag }}\left(r^{2}=0.75\right.$; Fig. 5). The fact that the correlation coefficients for each of the factors are similar $(0.75-0.8)$ 


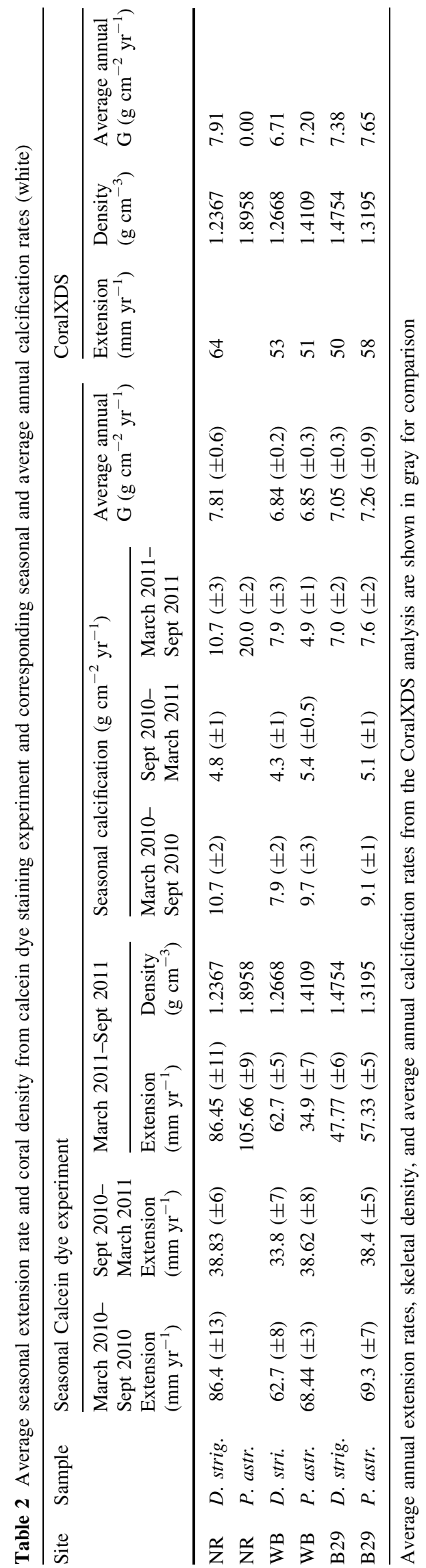

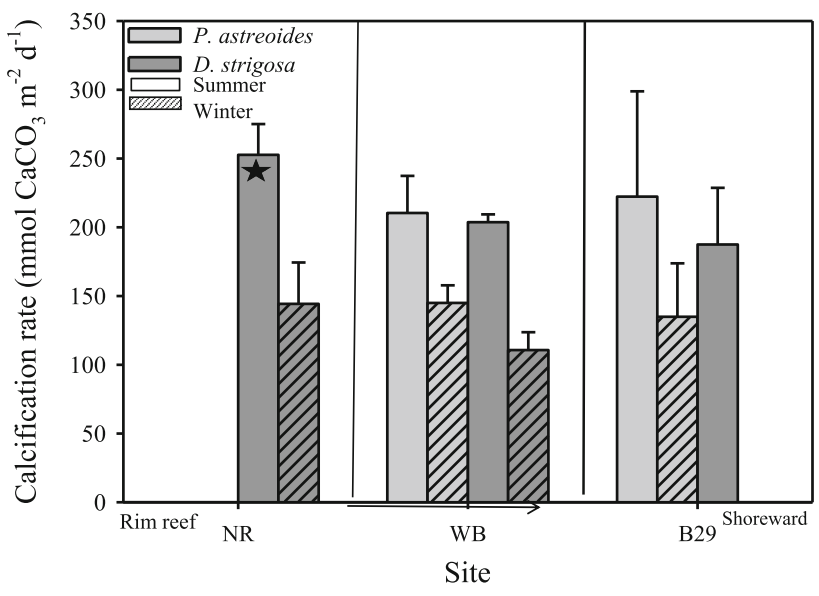

Fig. 4 Seasonal coral calcification rates averaged among three replicate samples of Porites astreoides (light gray) and Diploria strigosa (dark gray) measured from the seasonal calcein dye staining experiment. Open bars represent summertime rates (March-September); hashed bars represent winter rates (September-March). Error bars denote standard deviations among replicate species $(n=3)$. Study sites are shown as a function of their proximity to the rim reef, with NR closest to the rim reef, and progressing shoreward to WB and B29 along the $x$-axis. Calcification rates of $D$. strigosa at NR were statistically different from rates measured at WB or B29 (star). Calcein bands of $P$. asreoides at NR were not clear in all three replicate samples and thus are not shown. D. strigosa at B29 only displayed the final calcein sampling band (summer) in all three replicates, and thus, winter data are also not shown

does not mean that each factor contributed equally to the observed differences in calcification rate, but rather that the factors covary over time, i.e., temperature, light, and $\Omega_{\text {arag }}$ are highest during the summer and lowest during the winter. Increasing solar irradiance causes the water to warm. Warmer temperatures result in lower solubility of $\mathrm{CO}_{2}$ in seawater and lower aragonite solubility, which contribute to an increase in seawater $\Omega_{\text {arag. Increasing solar }}$ irradiance also affects net community production and calcification, which could alter $\Omega_{\text {arag }}$ depending on the relative uptake of DIC and TA (Andersson and Gledhill 2013). We discuss the cause and effect between these changes and the calcification rates of the corals in the subsequent discussion.

\section{Hourly light/dark calcification rates}

Hourly incubation experiments were conducted just after maximum temperatures were reached at our three study sites, in September 2010 and 2011 (indicated by the stars in Fig. 3). Average hourly calcification rates for $D$. strigosa $(n=5)$ ranged from $-32( \pm 20) \mathrm{mmol} \mathrm{CaCO}_{3} \mathrm{~m}^{-2} \mathrm{~h}^{-1}$ in 2010 to $14( \pm 6) \mathrm{mmol} \mathrm{CaCO}_{3} \mathrm{~m}^{-2} \mathrm{~h}^{-1}$ in 2011 under dark treatments and light treatments ranged from $7( \pm 6) \mathrm{mmol}$ $\mathrm{CaCO}_{3} \mathrm{~m}^{-2} \mathrm{~h}^{-1}$ in 2011 to $40( \pm 26) \mathrm{mmol}^{\mathrm{CaCO}_{3}}$ $\mathrm{m}^{-2} \mathrm{~h}^{-1}$ in 2011 under light treatments. Average hourly 

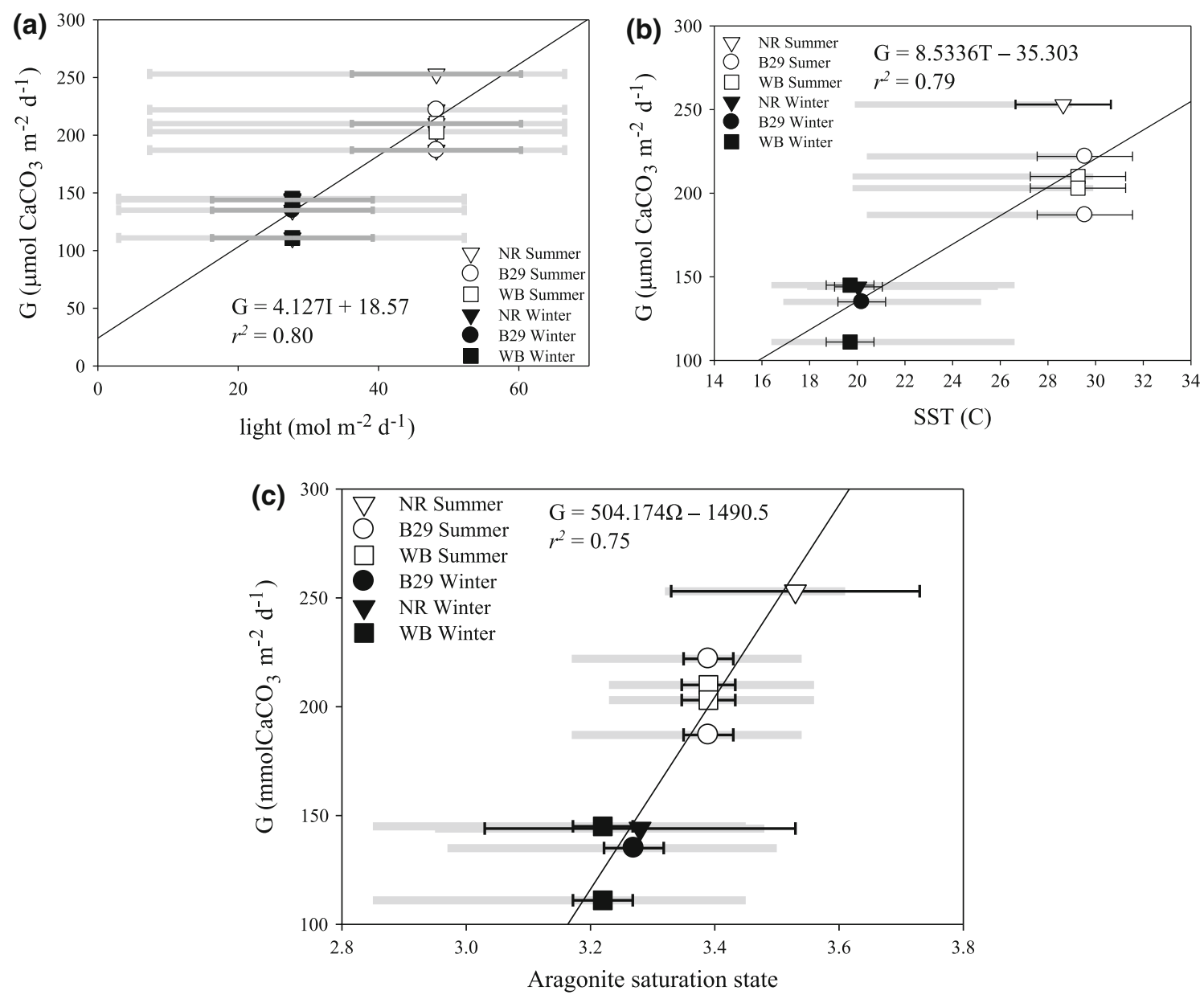

Fig. 5 Summer (open) and winter (filled) coral calcification rates averaged among replicate samples of $P$. astreoides and $D$. strigosa and corresponding a light, $\mathbf{b}$ sea surface temperature, and $\mathbf{c}$ aragonite saturation states at three study sites distributed across the northern Bermuda coral reef platform. Gray bars represent the observed seasonal range (Fig. 2); black bars represent average diurnal range;

calcification rates for $P$. astreoides $(n=5)$ ranged from $-34( \pm 21) \mathrm{mmol} \mathrm{CaCO}_{3} \mathrm{~m}^{-2} \mathrm{~h}^{-1}$ in 2010 to $24( \pm 35)$ $\mathrm{mmol} \mathrm{CaCO} \mathrm{m}^{-2} \mathrm{~h}^{-1}$ in 2011 in dark treatments and from

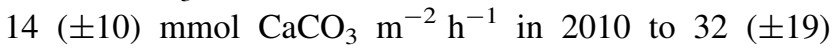
mmol CaCO${ }_{3} \mathrm{~m}^{-2} \mathrm{~h}^{-1}$ in 2011 in light treatments (Fig. 6). Average hourly calcification rates in light and dark treatments showed no significant difference between the three study sites for either species $P$. astreoides and $D$. strigosa (ANOVA, $F_{(2,19)}=0.06, p>0.05$; Fig. 6). However, the calcification rates between light and dark treatments were significantly different (ANOVA, $F_{(1,19)}=5.71, p<0.05$; Fig. 6). Average seawater $\mathrm{pH}$ and $\Omega_{\mathrm{arag}}$ were lower during dark treatments compared with light treatments in both 2010 and 2011 (Table 3). Light levels were similar during 2010 and 2011 sampling periods, while SST was about $2{ }^{\circ} \mathrm{C}$ cooler in 2011 (Table 3). Temperature and light did not change during the 1.5 -h incubation period and were dark gray bars in figure a represent the standard deviation of the seasonal average. Diurnal ranges in SST and $\Omega_{\text {arag }}$ were based on measurements from NOAA PMEL $\mathrm{MAPCO}_{2}$ buoy systems at Hog Reef $\left(32.46^{\circ} \mathrm{N}, 64.83^{\circ} \mathrm{W}\right)$ and Crescent Reef $\left(32.40^{\circ} \mathrm{N}, 64.79^{\circ} \mathrm{W}\right)$ http://www.pmel.noaa.gov/co2/story/Coral+Reef+Moorings. Light data came from BAS-Serco and the Bermuda Weather Service

identical to water column values, but $\Omega_{\text {arag }}$ was altered by the coral's metabolism; thus, corals experienced a range of $\Omega_{\text {arag }}$ during the 1.5-h incubation. The values reported here are the average $\Omega_{\text {arag }}$ during the 1.5-h incubation; the complete range of $\Omega_{\text {arag }}$ each coral experienced during the 1.5-h incubation is shown in Fig. 7.

Sea surface temperatures, measured in the water column and not inside the chambers throughout the incubation, were constant throughout the 1.5 -h incubation period and did not vary between light and dark incubations. Temperature was only weakly correlated with hourly calcification rates $\left(r^{2}=0.06\right)$. Light levels also remained constant throughout the incubation period and were, like SST, weakly correlated with calcification rates $\left(r^{2}=0.25\right)$. Hourly calcification rates displayed greater correlation with the $\Omega_{\text {arag }}\left(r^{2}=0.53\right)$, which did vary throughout the 1.5 -h incubation (Fig. 7). 

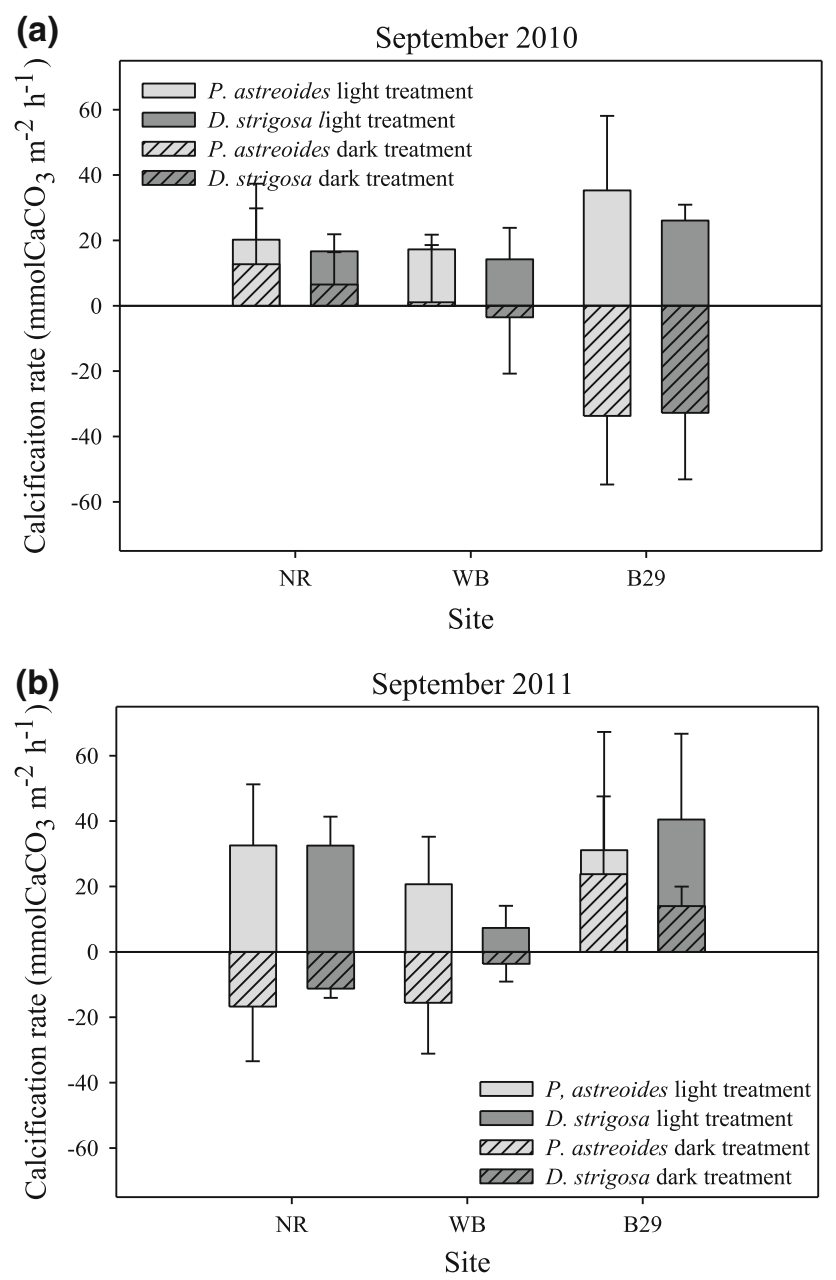

Fig. 6 Average hourly calcification rates from $\sim 1.5 \mathrm{~h}$ coral incubations in a September 2010 and b September 2011 under light (open) and dark (dashed) treatments for the two sample species Porites astreoides (light gray) and Diploria strigosa (dark gray). Results are averaged from five coral nubbins of each $P$. astreoides and D. strigosa at each of the three study sites. Error bars denote standard deviations. Study sites are shown as a function of their proximity to the rim reef, with NR closest to the rim reef and moving further away progressing along the $x$-axis

Spatial surveys of carbonate chemistry

During the March 2012 platform spatial survey, distributions of DIC and TA were high and relatively uniform across the Bermuda coral reef platform, with no clear trends. The March seawater DIC ranged from 2,067 to $2,094 \mu \mathrm{mol} \mathrm{kg}{ }^{-1}\left(\Delta \mathrm{DIC}=27 \mu \mathrm{mol} \mathrm{kg}{ }^{-1}\right)$, and TA ranged from 2,346 to $2,361 \mu \mathrm{mol} \mathrm{kg}{ }^{-1}$ $\left(\Delta \mathrm{TA}=15 \mu \mathrm{mol} \mathrm{kg}{ }^{-1}\right)$. The $\Omega_{\mathrm{arag}}$ was relatively uniform across the platform with an average of $3.08(\sigma=0.12$, $n=50$ ). Seawater $\mathrm{pCO}_{2}$ was also uniform with an average of $392 \mu \mathrm{atm}(\sigma=24, n=50)$.

The September distributions of carbon chemistry from the 2012 platform showed a drawdown of both DIC and TA compared with offshore values, with a large shoreward decline in both parameters. Dissolved inorganic carbon ranged from $2,047 \mu \mathrm{mol} \mathrm{kg}^{-1}$ at the rim reef to $1,938 \mu \mathrm{mol} \mathrm{kg}^{-1}$ nearshore $\left(\Delta \mathrm{DIC}=109 \mu \mathrm{mol} \mathrm{kg}{ }^{-1}\right)$, while TA ranged from 2,319 to $2,234 \mu \mathrm{mol} \mathrm{kg}{ }^{-1}$ $\left(\Delta \mathrm{TA}=85 \mu \mathrm{mol} \mathrm{kg}{ }^{-1}\right.$; Table 1$)$. The average $\Omega_{\text {arag }}$ was $3.29(\sigma=0.24, n=50)$, and the average $\mathrm{pCO}_{2}$ was $497.31 \mu$ atm $(\sigma=37.29, n=50)$.

To evaluate spatial trends in these distributions, the 50 stations were divided into seven cross-platform transects extending from shore to the rim reef. Data from stations at similar distances from shore were averaged and evaluated in reference to the average distance from shore. The significance of this average trans-platform trend was determined by testing the null hypothesis that the slope equaled zero $\left(\mathrm{H}_{0}: \beta=0\right)$. Based on this analysis, we observed no significant spatial trends in TA, DIC, or carbonate species $\mathrm{pCO}_{2}$ or $\Omega_{\text {arag }}$ in the March sampling survey (Table 4).

Despite greater variability of both $\mathrm{pCO}_{2}$ and $\Omega_{\text {arag }}$ in the September spatial survey, neither parameter displayed any statistically significant trend or gradient across the Bermuda coral reef platform (Table 4). When we averaged data from all rim reef stations and all nearshore stations, however, we found a significant difference of 0.14 units in the $\Omega_{\text {arag }}$ between these two regions of the platform (one sided $T$ test, $\left.t_{(16)}=2.82, p<0.05\right)$. These results agree with the monthly data, which show elevated $\Omega_{\text {arag }}$ at the rim reef (NC) compared with nearshore sites (TB and B33).

\section{Discussion}

Evaluation of the calcein staining method

The objective of this study was to resolve seasonal changes in coral growth rates and evaluate these changes in the context of variations in environmental conditions. Historically, alizarin red has been the method of choice to stain corals because it leaves a clear, pink stain, visible to the eye. However, sometimes the corals do not take the stain up effectively and data may be lost. There has also been concern that alizarin may be toxic to some corals (Dodge et al. 1984; Holcomb et al. 2013). For these reasons, we decided to use calcein dye for this study. The drawback of this stain is that it is not visible to the naked eye; it fluoresces when excited by $475 \mathrm{~nm}$ light. The advantages are that corals seem to take it up more reliably, and there is no reported negative impact to corals.

Though experiments employing calcein dye to measure intra-annual extension are becoming increasingly common in laboratory experiments, application of this method to in situ experiments has remained relatively limited until recently (Tambutte et al. 2011; Holcomb et al. 2013). To 
Table 3 Chemical and physical properties of water within the incubation chambers of the 2010 and 2011 hourly incubation study

\begin{tabular}{|c|c|c|c|c|c|c|c|c|c|c|}
\hline Year & Site & Treatment & coral species & Temp C & Salinity & $\begin{array}{l}\text { Light }(\mu \mathrm{mol} \\
\left.\text { photon } \mathrm{m}^{-2} \mathrm{~s}^{-1}\right)\end{array}$ & $\begin{array}{l}\text { TA } \\
\left(\mu \mathrm{mol} \mathrm{kg}{ }^{-1}\right)\end{array}$ & $\begin{array}{l}\text { DIC } \\
\left(\mu \mathrm{mol} \mathrm{kg}{ }^{-1}\right)\end{array}$ & $\mathrm{pH}$ & $\Omega_{\text {arag }}$ \\
\hline \multirow[t]{12}{*}{2010} & B29 & Light & P. astreoides & 27.78 & 36.86 & 486 & $2,233( \pm 20)$ & $1,917( \pm 19)$ & $7.97( \pm 0.01)$ & $3.22( \pm 0.08)$ \\
\hline & B29 & Light & D. strigosa & 27.78 & 36.86 & 486 & $2,272( \pm 8)$ & $1,951( \pm 11)$ & $7.97( \pm 0.01)$ & $3.25( \pm 0.04)$ \\
\hline & B29 & Dark & P. astreoides & 27.78 & 36.86 & 0 & $2,318( \pm 66)$ & $2,061( \pm 63)$ & $7.85( \pm 0.07)$ & $2.7( \pm 0.37)$ \\
\hline & B29 & Dark & D. strigosa & 27.78 & 36.86 & 0 & $2,333( \pm 30)$ & $2,058( \pm 34)$ & $7.88( \pm 0.02)$ & $2.86( \pm 0.07)$ \\
\hline & NR & Light & P. astreoides & 27.08 & 36.832 & 243 & $2,304( \pm 27)$ & $1,976( \pm 41)$ & $7.99( \pm 0.03)$ & $3.46( \pm 0.22)$ \\
\hline & NR & Light & D. strigosa & 27.08 & 36.832 & 243 & $2,273( \pm 34)$ & $1,938( \pm 34)$ & $7.98( \pm 0.02)$ & $3.30( \pm 0.12)$ \\
\hline & $\mathrm{NR}$ & Dark & P. astreoides & 27.08 & 36.832 & 0 & $2,377( \pm 23)$ & $2,107( \pm 43)$ & $7.87( \pm 0.06)$ & $2.84( \pm 0.28)$ \\
\hline & NR & Dark & D. strigosa & 27.08 & 36.832 & 0 & $2,371( \pm 30)$ & $2,093( \pm 26)$ & $7.87( \pm 0.02)$ & $2.85( \pm 0.13)$ \\
\hline & WB & Light & P. astreoides & 27.69 & 36.767 & 87 & $2,283( \pm 16)$ & $1,966( \pm 10)$ & $7.98( \pm 0.01)$ & $3.36( \pm 0.06)$ \\
\hline & WB & Light & D. strigosa & 27.69 & 36.767 & 87 & $2,272( \pm 24)$ & $1,955( \pm 20)$ & $7.98( \pm 0.02)$ & $3.33( \pm 0.11)$ \\
\hline & WB & Dark & P. astreoides & 27.69 & 36.767 & 0 & $2,359( \pm 30)$ & $2,075( \pm 45)$ & $7.89( \pm 0.06)$ & $2.95( \pm 0.32)$ \\
\hline & WB & Dark & D. strigosa & 27.69 & 36.767 & 0 & $2,338( \pm 45)$ & $2,070( \pm 13)$ & $7.88( \pm 0.05)$ & $2.88( \pm 0.31)$ \\
\hline \multirow[t]{12}{*}{2011} & B29 & Light & P. astreoides & 25.56 & 36.273 & 441 & $2,266( \pm 31)$ & $1,989( \pm 32)$ & $7.96( \pm 0.06)$ & $3.00( \pm 0.34)$ \\
\hline & B29 & Light & D. strigosa & 25.56 & 36.273 & 441 & $2,245( \pm 14)$ & $1,973( \pm 32)$ & $8.03( \pm 0.05)$ & $3.41( \pm 0.30)$ \\
\hline & B29 & Dark & P. astreoides & 25.56 & 36.273 & 0 & $2,289( \pm 20)$ & $2,052( \pm 38)$ & $7.96( \pm 0.06)$ & $3.04( \pm 0.31)$ \\
\hline & B29 & Dark & D. strigosa & 25.56 & 36.273 & 0 & $2,299( \pm 9)$ & $1,989( \pm 43)$ & $7.98( \pm 0.07)$ & $3.21( \pm 0.38)$ \\
\hline & NR & Light & P. astreoides & 25.56 & 36.323 & 206 & $2,266( \pm 19)$ & $1,960( \pm 16)$ & $8.04( \pm 0.01)$ & $3.44( \pm 0.08)$ \\
\hline & NR & Light & D. strigosa & 25.56 & 36.323 & 206 & $2,252( \pm 21)$ & $2,010( \pm 45)$ & $7.96( \pm 0.09)$ & $2.97( \pm 0.45)$ \\
\hline & NR & Dark & P. astreoides & 25.56 & 36.323 & 0 & $2,328( \pm 15)$ & $2,033( \pm 16)$ & $8.00( \pm 0.03)$ & $3.30( \pm 0.14)$ \\
\hline & NR & Dark & D. strigosa & 25.56 & 36.323 & 0 & $2,324( \pm 11)$ & $2,040( \pm 46)$ & $7.95( \pm 0.02)$ & $3.02( \pm 0.13)$ \\
\hline & WB & Light & P. astreoides & 26.11 & 36.227 & 58 & $2,231( \pm 16)$ & $1,941( \pm 10)$ & $8.04( \pm 0.05)$ & $3.39( \pm 0.31)$ \\
\hline & WB & Light & D. strigosa & 26.11 & 36.227 & 58 & $2,240( \pm 21)$ & $1,964( \pm 8)$ & $8.02( \pm 0.07)$ & $3.26( \pm 0.41)$ \\
\hline & WB & Dark & P. astreoides & 26.11 & 36.227 & 0 & $2,302( \pm 45)$ & $2,028( \pm 56)$ & $7.97( \pm 0.01)$ & $3.08( \pm 0.09)$ \\
\hline & WB & Dark & D. strigosa & 26.11 & 36.227 & 0 & $2,286( \pm 31)$ & $2,039( \pm 34)$ & $7.93( \pm 0.02)$ & $2.86( \pm 0.10)$ \\
\hline
\end{tabular}

TA, DIC, $\mathrm{pH}$, and $\Omega_{\text {arag }}$ change throughout the 1.5-h incubation; values reported here represent the average from the beginning and end of the incubation. Temperature, salinity, and light did not vary throughout the 1.5-h incubation. Values represent the average among replicate samples from each species (P. astreoides and D. strigosa, site (NR, WB, B29) and treatment (light and dark). Errors represent the standard deviation among replicates. Light values are given at depth (7 m for NR and WB, $3 \mathrm{~m}$ for B29), applying a diffusive attenuation coefficient of -0.27

validate the application of calcein dye staining in situ, we compared our results with coral calcification rates assessed using CoralXDS, which provides average annual calcification rates based on annual extension and average coral density (Helmle et al. 2002). Calcification rates from the calcein dye staining method used in this study provide seasonal resolution, and as expected, summer rates (March-September) were higher than the annual average results provided by CoralXDS, while winter rates (September-March) were lower (Fig. 8). In an effort to compare these two methods of measuring coral calcification rates, seasonal rates were converted to annual rates by assuming two 6-month growth periods with rates defined as the average winter and summer calcification rates determined from the seasonal staining study. These average annual calcification rates, scaled temporally from the seasonal staining study, were well correlated with average annual calcification rates obtained from CoralXDS $\left(r^{2}=0.85, \quad p=0.0004, n=18 ; \quad\right.$ Fig. $)$. The good agreement between these two methods suggests that calcein dye staining is an effective method for obtaining in situ seasonal coral extension rates.

Environmental controls on seasonal differences in growth rates

Previous studies investigating seasonal differences in coral calcification rates show a range of differences between summer and winter rates (Table 5; Gladfelter et al. 1978; Dodge and Brass 1984). Part of this difference is attributed to differences in environmental conditions associated with location and latitude. For example, low latitude reefs that experience small seasonal differences also show small differences between summer and winter calcification rates. However, part of the observed differences in seasonal calcification rates may be related to methodological challenges such as the aforementioned problems with alizarin staining. In contrast to low latitude locations, Bermuda 

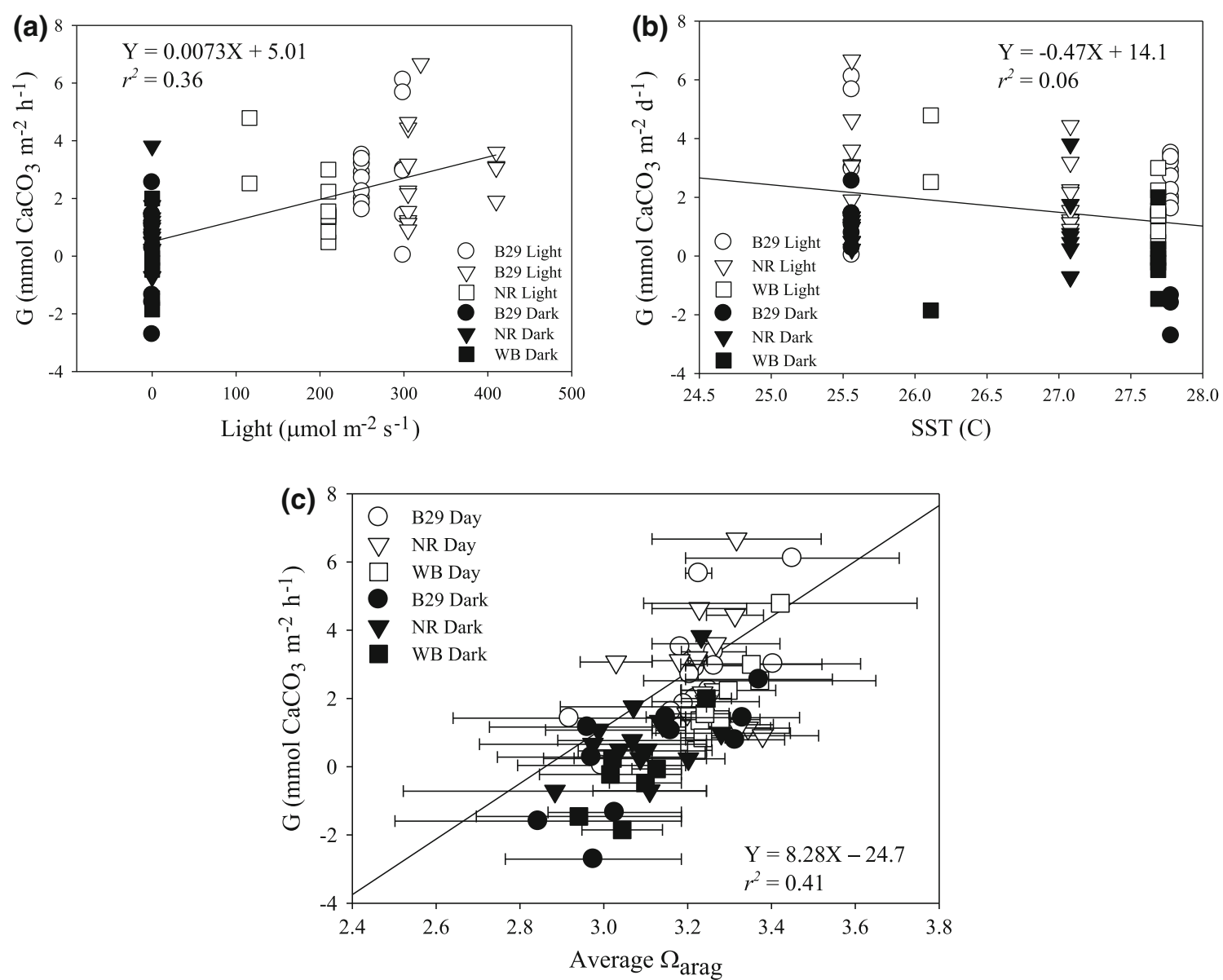

Fig. 7 Hourly coral calcification rates under light (open) and dark (filled) treatments and corresponding a light, b temperature, and c aragonite saturation states within each incubation chamber at three study sites distributed across the northern Bermuda reef platform. Error bars in c represent the range of aragonite saturation states

Table 4 Summary of the statistics of spatial trends across the Bermuda northern reef platform from the March and September 2012 spatial surveys

\begin{tabular}{|c|c|c|c|c|c|c|}
\hline \multirow[t]{2}{*}{ Parameter } & \multicolumn{3}{|l|}{ March } & \multicolumn{3}{|c|}{ September } \\
\hline & $t$ & $d f$ & $\begin{array}{l}\text { Significant at } \\
p=0.01 \mathrm{Y} / \mathrm{N}\end{array}$ & $t$ & $d f$ & $\begin{array}{l}\text { Significant at } \\
p=0.01 \mathrm{Y} / \mathrm{N}\end{array}$ \\
\hline DIC & 0.07 & 9 & $\mathrm{~N}$ & 8.99 & 9 & $\mathrm{Y}$ \\
\hline TA & 1.67 & 9 & $\mathrm{~N}$ & 6.09 & 9 & $\mathrm{Y}$ \\
\hline$\Omega_{\text {arag }}$ & 0.14 & 9 & $\mathrm{~N}$ & 1.34 & 9 & $\mathrm{~N}$ \\
\hline $\mathrm{pCO}_{2}$ & -0.22 & 9 & $\mathrm{~N}$ & 0.16 & 9 & $\mathrm{~N}$ \\
\hline
\end{tabular}

For this analysis, 50 sampling stations (Fig. 1) were divided into seven transects extending from the island of Bermuda out to the rim reef. Data from stations at similar distances from shore were then averaged to generate one average cross-platform transect. These data were then plotted as a function of their proximity to shore, testing the null hypothesis that the slope of this average cross-platform transect was zero $\left(\mathrm{H}_{0}: \beta=0\right)$ experience by each coral during the roughly $1.5-\mathrm{h}$ incubation period. $\Omega_{\text {arag }}$ is highest at the beginning and decrease throughout the incubation period. Light and temperature remained constant throughout the 1.5-h incubation

experiences large seasonality due to its relatively high latitude $\left(32^{\circ} \mathrm{N}\right)$, which results in large differences in coral calcification rates between summer and winter, with an average $\Delta \mathrm{G}$ between seasons of $77( \pm 29) \mathrm{mmol} \mathrm{CaCO}_{3}$ $\mathrm{m}^{-2} \mathrm{~d}^{-1}$, compared with studies from lower latitude reefs, such as the Great Barrier Reef $(\Delta \mathrm{G}=49$, Barnes and Lough 1993; Table 5).

The large seasonal difference in coral calcification rates observed in the present study combined with monthly measurements of environmental parameters (temperature, light, and $\Omega_{\text {arag }}$ ) make it possible to assess the correlation between these parameters and the calcification rates. Corals experienced significantly different average SST, light, and $\Omega_{\text {arag }}$ during the two growth periods (Fig. 3). The correlations shown in Fig. 5 suggest that each of the factors alone could conceivably explain the observed differences in seasonal growth. Of course, the strong correlations are 


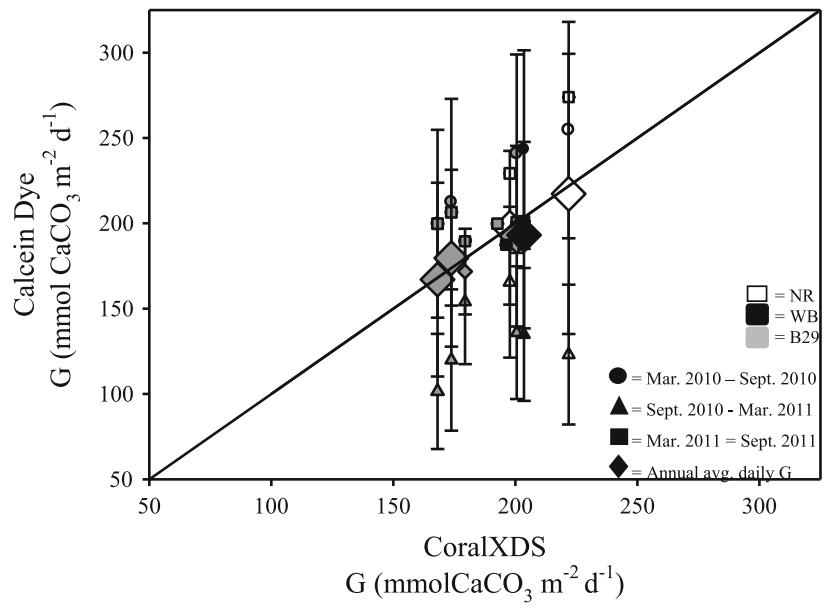

Fig. 8 Comparison of calcification rates measured using Coral XDS (annual rates) and calcein dye staining method (seasonal and annual average rates). Summer sampling periods are indicated by circles and squares; triangles indicate winter sampling period; and diamonds represent the average of winter and summer rates. The line designates a 1:1 ratio; points above this line indicate the calcein dying method overestimates calcification with respect to Coral XDS results; points below the line indicate the calcein dye method underestimates calcification. Average seasonal calcification from the calcein dye staining method agree well with results determined from CoralXDS $\left(r^{2}=0.85, p=0.0004, n=18\right)$

partly the result of the fact that we are working with only two sets of observations (March-September and September-March). We also know that light, temperature, and saturation state covary on both seasonal and hourly timescales. Therefore, we need to move beyond simple correlations in order to evaluate what is controlling the calcification rates measured in this study.

Silverman et al. (2009) and Anthony et al. (2011) took the approach of defining functions that attempted to describe the combined effects of temperature and $\Omega_{\text {arag }}$ on coral calcification. These functions did not include the effect of light, which certainly is important in explaining seasonal differences nor did they take into account that coral growth often has an asymmetric response to temperature (Houck et al. 1975; Reynaud et al. 1999). We make the assumption that the seasonal change in coral growth can be described by a partial differential equation of the form:

$\Delta G_{(s-w)}=\frac{\partial G}{\partial I} \Delta I+\frac{\partial G}{\partial T} \Delta T+\frac{\partial G}{\partial \Omega_{\mathrm{arag}}} \Delta \Omega_{\mathrm{arag}}$

where $\Delta G_{(s-w)}$ is the difference between summer and winter coral calcification rates, $\frac{\partial G}{\partial I}, \frac{\partial G}{\partial T}$, and $\frac{\partial G}{\partial \Omega_{\text {arag }}}$, are partial derivatives that describe the sensitivity of coral calcification $(G)$ to a unit change in light, temperature and $\Omega_{\mathrm{arag}}$ when the other factors are held constant and $\Delta I, \Delta T$, and $\Delta \Omega_{\text {arag, are }}$ the measured seasonal change in light, temperature, and
$\Omega_{\text {arag }}$, respectively. Essentially, we are assuming that the growth rate of the corals $(G)$ is a surface in 3-dimensional space (R3) and the three dimensions are light, temperature, and $\Omega_{\text {arag }}$. The slope of the gradient in this R3 space is given by Eq. (3) where each of the terms is a vector and the sum of these vectors gives the change in $\mathrm{G}$ due to the change in the three environmental factors. We estimate the gradient along each of the three dimensions (axes) based on available laboratory studies. Obviously, this model is very simplistic and ignores covariance terms and the influence of other factors such as food availability, nutrients, and water flow, but it represents a starting point to evaluate whether we can come close to predicting the magnitude of the seasonal change in calcification by considering just three factors and laboratory data on how the rate of calcification changes when each of these factors is varied individually.

\section{Light}

Coral calcification rates are strongly dependent on light availability. While many studies have looked at the shortterm response of coral calcification to changes in light on an hourly or day/night time scale (Gattuso et al. 1999; Anthony et al. 2007), what is needed for the present analysis is how coral calcification varies in response to the slow change in daily integrated irradiance that occurs over many days to weeks. On this timescale, the coral-algal symbiosis has time to photo-acclimate to changing light conditions, thereby optimizing its performance through changes in pigment content per symbiont, symbiont density, and even changes in symbiont genotype. Marubini et al. (2001) incubated replicate colonies of Porites compressa at different light levels for 6 weeks and determined that the relationship between photo-acclimated growth rate, and the average daily PAR was well described by the same hyperbolic tangent function used to describe the instantaneous rate of light calcification (Chalker 1981) and ranged from 7.8 to 9.0 mol photons $\mathrm{m}^{-2} \mathrm{~d}^{-1}$ per unit change in $\mathrm{G}$ and averaged $8.4 \mathrm{~mol}$ photons $\mathrm{m}^{-2} \mathrm{~d}^{-1}$ per unit change in $G$. The change in $G$ due to light $(\Delta G)$ is then given by:

$\Delta G=G_{\max } *\left(\tanh \left(\frac{E_{1}}{I_{k}}\right)-\tanh \left(\frac{E_{2}}{I_{k}}\right)\right)$

where $G_{\max }$ is the light-saturated rate of growth in $\mathrm{mg} \mathrm{cm}{ }^{-2} \mathrm{~d}^{-1}, E_{1}$ and $E_{2}$ are the daily integrated photosynthetically available light at time 1 and time 2 , and $I_{k}$ is the light saturation parameter in units of mol photons $\mathrm{m}^{-2} \mathrm{~d}^{-1}$.

The first step in determining the effect of the seasonal change in light is to estimate the amount of light that reaches the corals. The light at depth is given by $I_{\mathrm{o}} \exp$ $\left(-k_{z}^{*} z\right)$ where $I_{\mathrm{o}}$ is the incident PAR at the water surface, $k_{z}$ 
Table 5 Seasonal coral calcification rates

\begin{tabular}{|c|c|c|c|c|c|c|}
\hline Study & Study site & Method & $\begin{array}{l}\text { Growth } \\
\text { period }\end{array}$ & $\begin{array}{l}\text { Coral } \\
\text { species }\end{array}$ & $\begin{array}{l}G(\mathrm{mmol} \\
\left.\mathrm{CaCO}_{3} \mathrm{~m}^{-2} \mathrm{~d}^{-1}\right)\end{array}$ & $\begin{array}{l}\text { Seasonal } \Delta G \\
\left(\mathrm{mmol} \mathrm{CaCO}_{3} \mathrm{~m}^{-2} \mathrm{~d}^{-1}\right)\end{array}$ \\
\hline Gladfelter et al. (1978) & St Croix, USVI & X-ray & Summer & M. annularis & $355( \pm 24)$ & 73 \\
\hline Gladfelter et al. (1978) & St Croix, USVI & X-ray & Winter & M. annularis & $282( \pm 21)$ & \\
\hline Gladfelter et al. (1978) & St Croix, USVI & X-ray & Summer & M. annularis & $299( \pm 18)$ & -81 \\
\hline Gladfelter et al. (1978) & St Croix, USVI & X-ray & Winter & M. annularis & $380( \pm 18)$ & \\
\hline Gladfelter et al. (1978) & St Croix, USVI & X-ray & Summer & P. astreoides & $143( \pm 13)$ & 7 \\
\hline Gladfelter et al. (1978) & St Croix, USVI & X-ray & Winter & P. astreoides & $136( \pm 8)$ & \\
\hline Barnes and Lough (1993) & Central BGR & X-ray & Summer & Porites & $372( \pm 33)$ & 49 \\
\hline Barnes and Lough (1993) & Central BGR & X-ray & Winter & Porites & $323( \pm 32)$ & \\
\hline Dodge and Brass (1984) & Gulf of Mexico & X-ray & Summer & M. annularis & $291( \pm 33)$ & 32 \\
\hline Dodge and Brass (1984) & Gulf of Mexico & X-ray & Winter & M. annularis & $259( \pm 32)$ & \\
\hline This study & Bermuda, WB & Staining/X-ray & Summer & P. astreoides & $210( \pm 27)$ & 65 \\
\hline This study & Bermuda, WB & Staining/X-ray & Winter & P. astreoides & $145( \pm 13)$ & \\
\hline This study & Bermuda, B29 & Staining/X-ray & Summer & P. astreoides & $222( \pm 77)$ & 87 \\
\hline This study & Bermuda, B29 & Staining/X-ray & Winter & P. astreoides & $135( \pm 39)$ & \\
\hline This study & Bermuda, NR & Staining/X-ray & Summer & D. strigosa & $253( \pm 22)$ & 109 \\
\hline This study & Bermuda, NR & Staining/X-ray & Winter & D. strigosa & $144( \pm 30)$ & \\
\hline This study & Bermuda, WB & Staining/X-ray & Summer & D. strigosa & $204( \pm 51)$ & 93 \\
\hline This study & Bermuda, WB & Staining/X-ray & Winter & D. strigosa & $111( \pm 13)$ & \\
\hline
\end{tabular}

is the diffuse attenuation coefficient for PAR, and $z$ is the depth in $\mathrm{m}$. No data could be found for $k_{z}$ on the Bermuda platform. We recognize that $k_{z}$ varies both temporally and spatially due to changes in suspended particulates. The turbidity of the water in Bermuda varies between high in summer and low in winter. Certain areas of the reef platform (particularly B29) experience high turbidity following the passing of cruise ships. Given the lack of seasonal and spatial data on $k_{z}$ on the Bermuda platform, we make the assumption that it is similar to the value we have measured in the upper Florida Keys and on Davies Reef in the Great Barrier Reef, i.e., $-0.3 \mathrm{~m}^{-1}$ (C. Langdon unpublished data). Making this assumption, we believe that the attenuation coefficient is on the high end, and hence, our estimate of the effect of light on calcification will be on the conservative or low side. Based on the depth of our corals at approximately $5 \mathrm{~m}$ at our three study sites, we compute that the average light levels as 12.3 mol photons $\mathrm{m}^{-2} \mathrm{~d}^{-1}$ for the summer (March-September) growth period and $7.2 \mathrm{~mol}$ photons $\mathrm{m}^{-2} \mathrm{~d}^{-1}$ for winter (September-March). If we plug in 12.3 and 7.2 as E1 and E2, 8.4 as $I_{k}$, and 215 as $G_{\max }$ into Eq. (4), we find that the change in light could account for a $44 \mathrm{mmol} \mathrm{m} \mathrm{m}^{-2} \mathrm{~d}^{-1}$ decrease in calcification rate between summer (March-September) and winter (SeptemberMarch) or $54 \%$ of the total seasonal change. If $k_{z}$ is significantly greater than $0.3 \mathrm{~m}^{-1}$ during the winter (September-March) period, then light could play an even greater role in driving the seasonal change in $G$.

\section{Temperature}

Data on the effect of temperature on coral growth in wellcontrolled experimental studies is sparse, but based on what we have been able to find, the effect is symmetric about the temperature optimum for some species and asymmetric for others (Table 6). These temperature studies did not account for the corresponding change in $\Omega_{\text {arag }}$, which also affects calcification. Though we recognize this as a limitation of our estimate of the effect of temperature on calcification, we argue that the corresponding change in $\Omega_{\text {arag }}$, due to a change in temperature is small and will therefore have a minimal influence on calcification in comparison with temperature. A $2{ }^{\circ} \mathrm{C}$ change in temperature results in a 0.03 unit change in $\Omega_{\text {arag. If we assume a }}$ $15 \%$ change in calcification for every unit change in $\Omega_{\text {arag }}$ (Chan and Connolly 2013), this results in a $0.45 \%$ change in $G$, which is small compared with the influence of temperature. We find that on average growth rate decreases by $12 \pm 4 \%{ }^{\circ} \mathrm{C}^{-1}$ below the species temperature optimum and decreases by $24 \pm 17 \%{ }^{\circ} \mathrm{C}^{-1}$ when temperature exceeds the temperature optimum. Utilizing this information in our study requires knowing the temperature optimum for our species. We could find nothing in the literature specific to the two species used in this study or for corals growing on the Bermuda platform. In general, temperature optima of tropical corals range from 25 to $29{ }^{\circ} \mathrm{C}$ (Vaughan and Wells 1943). However, the optimum is specific to the range of temperature that the corals 
Table 6 Examples of the effect of temperature both above and below the optimal temperature for coral growth $\left(T_{\text {opt }}\right.$.) on coral calcification rates

\begin{tabular}{|c|c|c|c|c|c|}
\hline Species & Origin of colonies & $\begin{array}{l}T\left({ }^{\circ} \mathrm{C}\right) \\
\text { rang }\end{array}$ & $\begin{array}{l}\% \text { change in } \mathrm{G} \\
\text { per }{ }^{\circ} \mathrm{C} \text { for } T<T_{\text {opt. }}\end{array}$ & $\begin{array}{l}\% \text { change in } \mathrm{G} \\
\text { per }{ }^{\circ} \mathrm{C} \text { for } T>T_{\text {opt }} .\end{array}$ & Reference \\
\hline M. capitata & Kaneohe Bay, HI & $20-28$ & 8 & -8 & Coles et al. (1976) \\
\hline P. lobata & Kaneohe Bay, HI & $22-28.5$ & 11.1 & -57 & Houck et al. (1975) \\
\hline G. fascicularis & Heron Reef, GBR & $21-29$ & 15.2 & -18 & $\begin{array}{l}\text { Marshall and Clode (2004), } \\
\text { Al Horani (2005) }\end{array}$ \\
\hline S. pistilata & Gulf of Aqaba & $21-29$ & 8.1 & -32 & Reynaud et al. (1999) \\
\hline Acropora sp. & Gulf of Aqaba & $21-29$ & 6.9 & -9 & Reynaud et al. (1999) \\
\hline P. damicornis & $\begin{array}{l}\text { Kaneohe Bay, HI } \\
\text { Eniwetok Atoll, } \\
\text { Marshall Islands }\end{array}$ & $22.6-28$ & 16.9 & -18 & Clausen and Roth (1975) \\
\hline Average & & & 12 & -24 & \\
\hline SD & & & 4 & 17 & \\
\hline
\end{tabular}

experience at a specific location. Jokiel and Coles (1974) found that the temperature optima for Pocillopora damicornis ranged from $31{ }^{\circ} \mathrm{C}$ for specimens collected at Eniwetok $(11.5 \mathrm{~N})$ to $27{ }^{\circ} \mathrm{C}$ for corals collected in Kaneohe Bay, Oahu (21 N) to $23{ }^{\circ} \mathrm{C}$ for corals collected at Midway Atoll ( $28 \mathrm{~N})$. Based on these studies, it can be inferred that the optima is close to or slightly above the average annual temperature that the species encounters. The annual average SST for the Bermuda coral reef platform from 2010 to 2011 was $23.4{ }^{\circ} \mathrm{C}$ (Fig. 3) with a summer maximum of $29^{\circ} \mathrm{C}$. Even though Bermuda is located at a higher latitude $\left(32^{\circ} \mathrm{N}\right)$ than Midway, it experiences summer temperatures that are approximately $2{ }^{\circ} \mathrm{C}$ warmer. Based on this, we assume that the temperature optimum of corals in Bermuda is in the $23.4-25.4{ }^{\circ} \mathrm{C}$ range, but we recognize that this range could be broader and very likely span a higher temperature range. The percentage change in calcification between two temperatures is given by:

$$
\begin{aligned}
& \text { If } T_{\mathrm{L}}<T_{\text {opt }}<T_{\mathrm{H}} \text { : } \\
& \Delta \% G=\left(12 \%{ }^{\circ} \mathrm{C}^{-1}\right)\left(T_{\mathrm{opt}}-T_{\mathrm{L}}\right) \\
& +\left(-24 \%{ }^{\circ} \mathrm{C}^{-1}\right)\left(T_{\mathrm{H}}-T_{\text {opt }}\right) \\
& \text { If } T_{\mathrm{opt}}>T_{\mathrm{H}}: \quad \Delta \% G=\left(12 \%{ }^{\circ} \mathrm{C}^{-1}\right)\left(T_{\mathrm{H}}-T_{\mathrm{L}}\right)
\end{aligned}
$$

where $\Delta \% G$ is the percentage change in the rate of calcification, 12 and $-24 \%{ }^{\circ} \mathrm{C}^{-1}$ are the sensitivity of calcification to a unit change in temperature from Table $6, T_{\text {opt }}$ is the optimum temperature for growth, and $T_{\mathrm{L}}$ and $T_{\mathrm{H}}$ are the low and high temperatures of interest. $T_{\mathrm{L}}$ and $T_{\mathrm{H}}$ in this study are 21 and $25{ }^{\circ} \mathrm{C}$, respectively. Based on Eq. (5) and a $T_{\text {opt }}$ that ranges from 23.4 to $25.4{ }^{\circ} \mathrm{C}$, we compute that $\Delta \% G$ ranges from -10 to $+38 \%$ and averages $+24 \%$. If $T_{\text {opt }}$ exceeds $25.0{ }^{\circ} \mathrm{C}$ (Eq. 6), then the $\Delta \% G$ asymptotes out at $48 \%$. A $24 \%$ reduction in the summer (March-September) calcification rate amounts to a change of $52 \mathrm{mmol} \mathrm{m}^{-2} \mathrm{~d}^{-1}$. A $24 \%$ decrease in the winter (September-March) rates amounts to a change of $32 \mathrm{mmol} \mathrm{m} \mathrm{m}^{-2}$.
Seawater aragonite saturation state

Lastly, we consider the contribution from the 0.16 unit change in $\Omega_{\text {arag }}$ observed between summer and winter. Laboratory studies have found that the mean response of coral calcification is $-15 \pm 8 \%$ per unit decrease in $\Omega_{\text {arag }}$ (Chan and Connolly 2013). Based on this sensitivity we estimate that the change in $\Omega_{\text {arag }}$ would cause a $2.4 \%$ or $4 \mathrm{mmol} \mathrm{m} \mathrm{m}^{-2}$ change in coral calcification rate.

In order to compare the sensitivities (slope of calcification vs. $\Omega_{\text {arag }}$ relationship) measured in different studies, it is first necessary to normalize the data because the absolute rates may be different. A simple way to normalize the rates is to express them relative to a rate at a reference seawater aragonite saturation state. While any $\Omega_{\text {arag }}$ can be used, it is advantageous to use the pre-industrial average seawater $\Omega_{\text {arag }}$ of 4.6 because the rates then reflect the change since the onset of modern anthropogenic ocean acidification. For data sets where an equation of the form $y=m x+b$ has been provided, multiplying $\mathrm{m}$ by $[100 /$ $(m * 4.6+b)]$ yields a normalized slope or sensitivity that reflects the percentage change in calcification per unit

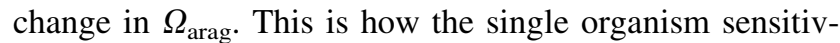
ities were compared in Chan and Connolly (2013), which showed an average of $15 \pm 8 \%$ change in $G$ per unit change in $\Omega_{\text {arag. }}$. The stronger sensitivity of $63 \%$ change in G per unit change in $\Omega_{\text {arag }}$ observed in this study for both hourly and seasonal calcification rates is much greater than that observed in controlled experiments (Fig. 9). A stronger sensitivity of community calcification to a change in $\Omega_{\text {arag }}$ has been previously noted (Pandolfi et al. 2011). This strong sensitivity results in a threshold $\Omega_{\text {arag }}$ of 2.97 , below which we should expect dissolution; however, we know that to be incorrect as corals on the Bermuda platform continue to calcify at $\Omega_{\text {arag }}<3.0$. With regard to the seasonal data, this strong sensitivity may be a result of the covariance of $\Omega_{\text {arag }}$ with other driving factors like 


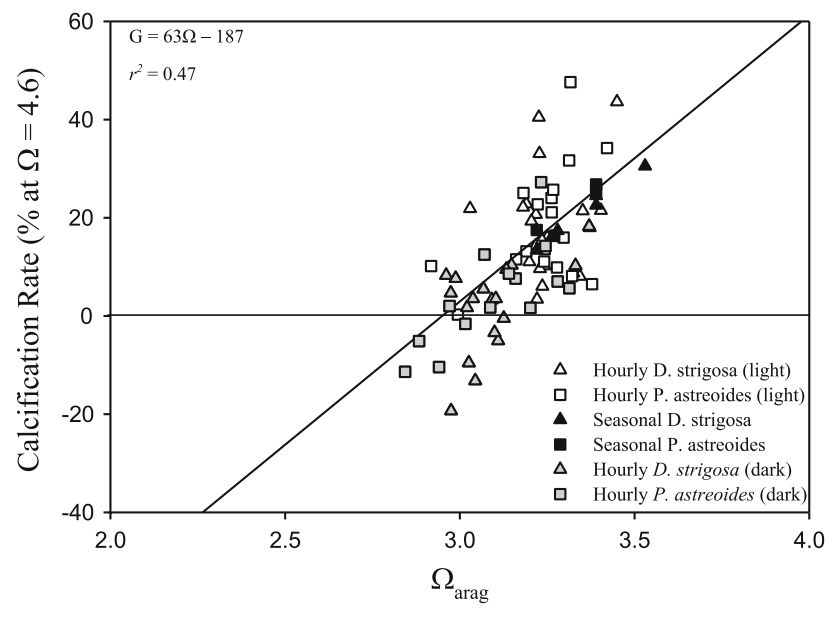

Fig. 9 Calcification rates from Diploria strigosa (triangles) and Porites astreoides (squares) from the dark (gray) and light (white) hourly incubation study and seasonal staining study (black) normalized to the calcification rate at $\Omega_{\text {arag }}=4.6$ and corresponding $\Omega_{\text {arag }}$. Hourly $\Omega_{\text {arag }}$ shown are the average values from the $\sim 1.5-\mathrm{h}$ incubation period. Seasonal average $\Omega_{\text {arag }}$ were determined from monthly water sampling by the Bermuda Ocean Acidification and Coral Reef Investigation (BEACON) project

temperature and light. With regard to the hourly incubation data, the strong sensitivity may be a result of the effects of respiration or dissolution on $\Omega_{\mathrm{arag}}$ within the chambers. Alternatively, if environmental conditions (e.g., light, temperature, food availability) in the field were sub-optimal, corals may be more sensitive to $\Omega_{\text {arag }}$ compared with corals reared in controlled environments where these parameters are maintained at optimal levels.

Controlling factors of seasonal coral calcification in Bermuda

In summary, our analysis suggests that light and temperature contribute roughly equally to the seasonal difference in calcification, i.e., $44-54 \mathrm{mmol} \mathrm{m}{ }^{-2} \mathrm{~d}^{-1}$ and the change in $\Omega_{\text {arag }}$ contributes about $4 \mathrm{mmol} \mathrm{m}^{-2} \mathrm{~d}^{-1}$. Thus, the total seasonal difference in calcification based on this assessment is roughly $102 \mathrm{mmol} \mathrm{m}^{-2} \mathrm{~d}^{-1}$, which is more than the observed change of $81 \pm 14 \mathrm{mmol} \mathrm{m}^{-2} \mathrm{~d}^{-1}$, suggesting that the cumulative effects of changing light, temperature, and saturation state are less than the individual effects based on experimental studies.

It is encouraging that the prediction is not significantly different from the observations, but the uncertainty of the prediction is undoubtedly large. Future work is required to better constrain the $I_{k}$ and $T_{\mathrm{opt}}$ of the Bermuda corals and determine if there are important covariance terms that we are ignoring.
Environmental controls on hourly differences in growth rates

During our short-term incubation experiments, we found the response of calcification to changes in light to be $0.007 \mathrm{mmol} \mathrm{m} \mathrm{m}^{-2} \mathrm{~h}^{-1}$, which is similar to that reported by Langdon and Atkinson $\left(2005 ; 0.01 \mathrm{mmol} \mathrm{m}^{-2} \mathrm{~h}^{-1}\right.$ ) and Gattuso et al. (1996; $\left.0.005 \mathrm{mmol} \mathrm{m}^{-2} \mathrm{~h}^{-1}\right)$. During the light incubations, $\Omega_{\text {arag }}$ increased by $0.13 \pm 0.06$ (SD) units, and during the dark incubation, it decreased by $0.18 \pm 0.07$ units. Calcification was similarly correlated with both light $\left(r^{2}=0.36\right)$ and $\Omega_{\text {arag }}\left(r^{2}=0.41\right.$; Fig. 7a,c). While the slope of $\mathrm{G}$ versus light plot (0.007 mmol m $\mathrm{m}^{-2} \mathrm{~h}^{-1}$ compares well with other studies, the slope of the G versus $\Omega_{\text {arag }}$ implies a sensitivity that is much greater than observed in other single organism laboratory studies. This can be seen by normalizing the hourly data as described above for the seasonal data (Fig. 9). The slope of the normalized hourly data is $63 \%$ per unit $\Omega_{\text {arag }}$, which is similar to that reported for the seasonal data and likewise four times greater than the average coral sensitivity (Chan and Connolly 2013). We think that this high sensitivity to $\Omega_{\text {arag }}$ is overestimated. Photosynthesis and respiration have a direct impact on $\Omega_{\text {arag }}$ (i.e., photosynthesis results in an increase in $\Omega_{\text {arag, }}$, while respiration decreases $\Omega_{\text {arag }}$, which in turn affect calcification rates. In this study, photosynthesis is causing $\Omega_{\text {arag }}$ to rise in the light incubations, and respiration is causing it to decline in the dark incubations. This net change in $\Omega_{\text {arag }}$ between the light and dark incubations is 0.13 units. Calcification rates of the corals do respond to these changes in $\Omega_{\text {arag }}$, but it is also responding to the light. The effect of light is much greater than the effect of $\Omega_{\mathrm{arag}}$. The average light received is sufficient to increase calcification rates by $0.0073 *$ (200-400) or $1.5-3 \mathrm{mmol} \mathrm{m}^{-2} \mathrm{~h}^{-1}$, while the 0.13 unit increase in $\Omega_{\text {arag }}$ probably increases $G$ by only $0.04 \mathrm{mmol} \mathrm{m}^{-2} \mathrm{~h}^{-1}$. In the dark incubation, the effect of the removal of light causes $G$ to abruptly decrease to the dark rate, while the decrease in $\Omega_{\text {arag }}$ probably only contributes a decrease of only $0.05 \mathrm{mmol} \mathrm{m}^{-2} \mathrm{~h}^{-1}$. The decrease in $\Omega_{\text {arag }}$ in the dark incubation may also cause the rate of dissolution to increase. This increase in dissolution may be why we see net dissolution in some of the chambers (Fig. 6).

The combination of decreased calcification and increased dissolution would result in an even larger decrease in $G$. The net effect of light and dark is to cause a large change in $G$ that looks like a very strong sensitivity to $\Omega_{\text {arag }}$ if the full change in $G$ is mapped onto the 0.31 unit change in $\Omega_{\text {arag }}$, but is actually largely due to light and perhaps also the stimulation of dissolution in the dark incubations. 
TA:DIC property-property plots and lack of a spatial gradient in $\Omega_{\text {arag }}$ across the platform

To understand why we are not seeing gradients in $\Omega_{\text {arag }}$ across the platform, which is a common feature of many reefs (Kawahata et al. 1997, 2000; Suzuki and Kawahata 2003; Watanabe et al. 2006; Albright et al. 2013), we turn to the plot of salinity-normalized TA versus DIC, which shows data points from the 50 station platform-wide surveys conducted in March and September 2012 (Fig. 10). The points tend to fall along a fairly tight line with a slope of $0.93 \pm 0.04$ that closely approximates the slope of the $\Omega_{\text {arag }}$ isopleths. This is not significantly different from the $1.05 \pm 0.04$ reported by Andersson et al. (2013). This means that the biota on the platform is removing DIC and TA from the water in a fairly constant ratio both temporally and spatially and that this ratio balances the effect of photosynthesis to elevate $\mathrm{pH}$ (reduce $\mathrm{pCO}_{2}$ ) and calcification to reduce $\mathrm{pH}$ (elevate $\mathrm{pCO}_{2}$; Andersson and Gledhill 2013). When the two processes combine in this ratio, the DIC and TA can be drawn far down from their source water values without altering the $\mathrm{pH}, \mathrm{pCO}_{2}$, or $\Omega_{\text {arag }}$ significantly. One consequence of this is that you do not find spatial gradients in $\mathrm{pH}, \mathrm{pCO}_{2}$, or $\Omega_{\text {arag }}$ as you do on many other reefs where the slope of the TA:DIC line tends to be lower.

Understanding the relationship of temperature, light, and $\Omega_{\text {arag }}$ on coral calcification rates requires high temporal and spatial resolution of environmental data. The monthly data showed sustained differences in $\Omega_{\text {arag }}$ and $\mathrm{pCO}_{2}$ at the rim reef (NC) compared with nearshore sites (TB and B33). The platform surveys in March and September, however, showed that despite significant differences between the rim reef and nearshore sites, there was no consistent or uniform spatial gradient across the platform. This highlights the importance of obtaining environmental data at both high spatial and temporal resolutions in order to understand how these parameters are influencing coral calcification rates.

Seasonal coral calcification rates were measured at three study sites across the Bermuda coral reef platform and showed a difference between seasons that was reasonably well explained by a simple linear model that combined the known sensitivity of coral growth to temperature, light, and $\Omega_{\text {arag }}$ from laboratory studies with the measured differences in temperature, light, and $\Omega_{\text {arag. }}$. We have presented a new way to assess the impact of different driving parameters on coral calcification rates, based on laboratory relationships between $G$ and environmental driving factors, and measured differences of these environmental factors. Based on these assessments, seasonal differences in coral calcification rates in Bermuda are driven mostly by the seasonal differences in temperature and light. Differences between hourly calcification rates under light and dark treatments are most likely driven by light, enhanced by the effect of

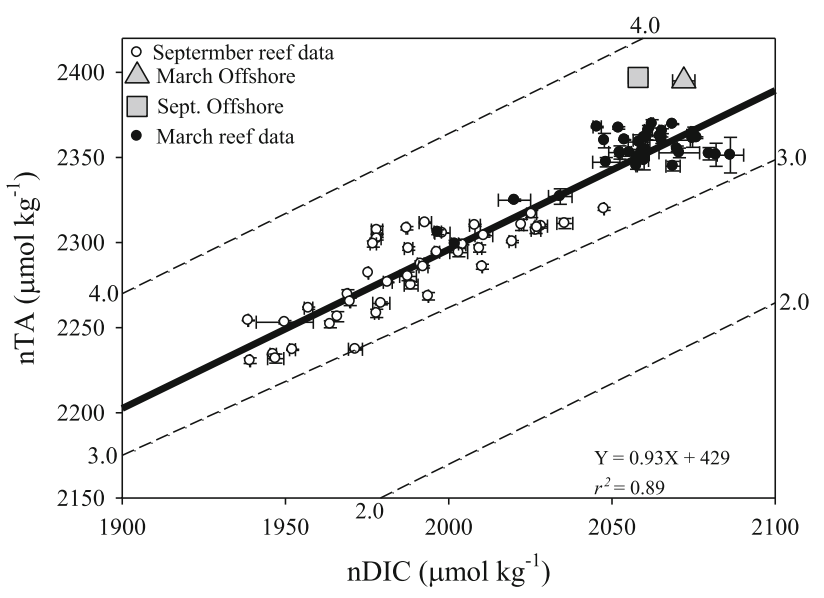

Fig. 10 Salinity normalized $(S=36.6)$ total alkalinity versus dissolved inorganic carbon from data collected at 50 sampling stations distributed across the Bermuda reef northern platform in March and September, 2012 (open circles), with offshore end members from samples collected in the Sargasso sea during corresponding reef sampling expeditions (filled triangle and square). Hashed lines are aragonite saturation state contours at $25{ }^{\circ} \mathrm{C}$. The slope of the type II linear regression of the reef data (black line) equals $0.93 \pm 0.04$ $\left(n=79, r^{2}=0.89\right)$

respiration and photosynthesis on $\Omega_{\text {arag }}$ under dark and light conditions, respectively.

Though the sensitivity of normalized calcification to a unit change in $\Omega_{\text {arag }}$ was found to be similar and high at hourly and seasonal time scales, i.e., $63 \%$ per unit change in

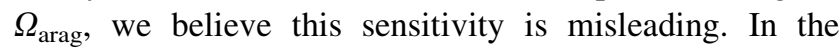
chamber study, this high sensitivity can be explained by the covariant nature of light and $\Omega_{\text {arag }}$, which both have a positive effect on calcification, with the former having a much stronger effect. In the seasonal study, this high sensitivity may be a result of the covariant nature of temperature, light, and $\Omega_{\text {arag. }}$. On the other hand, it is important not to underestimate the role that ocean acidification may play in controlling demographics in coming decades. Not assessed in field studies such as this one is the possibility that a unit change in saturation state, $\mathrm{pH}$, or $\mathrm{pCO}_{2}$ can have a much larger impact on growth or net photosynthesis when the temperature approaches the upper thermal limit of the coral, i.e., a synergistic interaction between $\mathrm{pH}$ and temperature (Anthony et al. 2008; Crawley et al. 2010; Kaniewska et al. 2012).

Open Access This article is distributed under the terms of the Creative Commons Attribution License which permits any use, distribution, and reproduction in any medium, provided the original author(s) and the source are credited.

\section{References}

Al-Horani FA (2005) Effect of changing seawater temperature on photosynthesis and calcification in the scleractinian coral 
Galaxea Fascicularis, measured with $\mathrm{O}_{2}, \mathrm{Ca}^{2+}$ and $\mathrm{pH}$ microsensors. Sci Mar 69:347-354

Albright R, Langdon C, Anthony KRN (2013) Dynamics of seawater carbonate chemistry, production, and calcification of a coral reef flat, Central Great Barrier Reef. Biogeosci Discuss 10:7641-7676

Andersson AJ, Gledhill D (2013) Ocean acidification and coral reefs: effects on breakdown, dissolution, and net ecosystem calcification. Annu Rev Mar Sci 5:321-348

Andersson AJ, Yeakel KL, Bates NR, de Putron SJ (2013) Partial offsets in ocean acidification from changing coral reef biogeochemistry. Nat Clim Chang 4:56-61

Andersson AJ, Mackenzie FT (2011) Technical comment on Kroeker et al. (2010) Meta-analysis reveals negative yet variable effects of ocean acidification on marine organisms. Ecol Lett 13:1419-1434

Anthony KRN, Maynard JA, Diaz-Pulido G, Mumby PJ, Marshall PA, Cao L, Hoegh-Gulberg O (2011) Ocean acidification and warming will lower coral reef resilience. Glob Change Biol 17:1798-1808

Anthony KRN, Kline DI, Dove S, Hoegh-Guldberg O (2008) Ocean acidification causes bleaching and productivity loss in coral reef builders. Proc Natl Acad Sci U S A 105:17442-17446

Anthony KRN, Connolly SR, Hoegh-Gulberg O (2007) Bleaching, energetics, and coral mortality risk: effects of temperature, light and sediment regime. Limnol Oceanogr 52:716-726

Barnes DJ, Lough JM (1993) On the nature and cause of density banding in massive coral skeletons. J Exp Mar Biol Ecol 167:109-125

Bates NR, Amat A, Andersson AJ (2010) Feedbacks and responses of coral calcification on the Bermuda reef system to seasonal changes in biological processes and ocean acidification. Biogeosciences 7:2509-2530

Chalker BE (1981) Simulating light-saturation curves for photosynthesis and calcification by reef-Building corals. Mar Biol 62:135-141

Chalker BE, Taylor DL (1975) Light-enhanced calcification, and the role of oxidative phosphorylation in calcification of the coral Acropora cervicornis. Proc R Soc Lond B Biol Sci 190:323-331

Chalker B, Barnes D, Isdale P (1985) Calibration of X-ray densitometry for the measurement of coral skeletal density. Coral Reefs 4:95-100

Chan NCS, Connolly SR (2013) Sensitivity of coral calcification to ocean acidification: a meta-analysis. Glob Change Biol 19:282-290

Clausen CD, Roth AA (1975) Effect of temperature and temperature adaptation on calcification rate in hermatypic coral Pocillopora damicornis. Mar Biol 33:85-91

Coles SL, Jokiel PL, Lewis CR (1976) Thermal tolerance in tropical versus subtropical Pacific reef corals. Pac Sci 30:159-166

Crawley A, Kline DI, Dunn S, Anthony KRN, Dove S (2010) The effect of ocean acidification on symbiont photorespiration and productivity in Acropora formosa. Glob Change Biol $16: 851-863$

Dickson AG, Millero FJ (1987) A comparison of the equilibriumconstants for the dissociation of carbonic-acid in seawater media. Deep Sea Res A 34:1733-1943

Dickson AG (1990) Thermodynamics of the dissociation of boric-acid in synthetic seawater from $273.15 \mathrm{~K}$ to $318.15 \mathrm{~K}$. Deep Sea Res A 37:755-766

Dodge RE, Brass GW (1984) Skeletal extension, density and calcification of the reef coral, Montastrea annularis: St. Croix, US Virgin Islands. Bull Mar Sci 34:288-307

Dodge RE, Wyers SC, Frith HR, Knap AH, Smith SR, Cook CB, Sleeter TD (1984) Coral calcification rates by the buoyant weight technique: effects of alizarin staining. J Exp Mar Biol Ecol 75:217-232

Gattuso J-P, Pichon M, Delesalle B, Canon C, Frankignoulle M (1996) Carbon flux in coral reefs. I. Lagrangian measurement of community metabolism and resulting air-sea $\mathrm{CO}_{2}$ disequilibrium. Mar Ecol Prog Ser 145:109-121

Gattuso J-P, Allemand D, Frankignoulle M (1999) Photosynthesis and calcification at cellular, organismal and community levels in coral reefs: A review on interactions and control by carbonate chemistry. Am Zool 39:160-183

Gladfelter EH, Monahan RK, Gladfelter WB (1978) Growth rates of five reef-building corals in the Northeastern Caribbean. Bull Mar Sci 28:728-734

Gordeau TF (1959) The physiology of skeleton formation in corals 1. A method for measuring the rate of calcium deposition by corals under different conditions. Biol Bull 116:59-75

Goreau TF, Goreau NI (1959) The physiology of skeleton formation in corals 2. Calcium deposition by hermatypic corals under various conditions in the reef. Biol Bull 117:239-250

Hansson I, Janger D (1973) Evaluation of the accuracy of gran plots by means of computer calculations: Application to the potentiometric titration of the total alkalinity and carbonate content in sea water. Anal Chim Acta 65:363-373

Helmle KP, Dodge RE, Ketcham RA (2002) Skeletal architecture and density banding in Diploria strigosa by X-ray computed tomography. Proc $9^{\text {th }}$ Int Coral Reef Symp 1:365-371

Hoegh-Guldberg O, Mumby PJ, Hooten AJ, Steneck RS, Greenfield P, Gomez E, Harvell CD (2007) Coral reefs under rapid climate change and ocean acidification. Science 318:1737-1742

Holcomb M, Cohen AL, McCorkle DC (2013) An evaluation of staining techniques for marking daily growth in scleractinian corals. J Exp Mar Biol Ecol 440:126-131

Houck JE, Buddemeier RW, Chave KE (1975) Skeletal lowmagnesium calcite in living scleractinian corals. Science 189:997-999

Jokiel PL, Coles SL (1974) Effects of heated effluent on hermatypic corals at Kahe-Point, Oahu. Pac Sci 28:1-18

Kaniewska P, Campbell PR, Kline DI, Rodriguez-Lanetty M, Miller DJ, Dove S, Hoegh-Guldberg O (2012) Major cellular and physiological impacts of ocean acidification on a reef building coral. PLoS One 7:e34659

Kawaguti S, Sakumoto D (1948) The effect of light on the calcium deposition of corals. Bull Oceanogr Inst Taiwan 4:65-70

Kawahata H, Suzuki A, Ayukai T, Goto K (2000) Distribution of the fugacity of carbon dioxide in the surface seawater of the Great Barrier Reef. Mar Chem 72:257-272

Kawahata H, Suzuki A, Goto K (1997) Coral reef ecosystems as a source of atmospheric $\mathrm{CO}_{2}$ : Evidence from $\mathrm{pCO}_{2}$ measurements of surface waters. Coral Reefs 16:261-266

Kleypas JA, Buddemeier RW, Archer D, Gattuso J-P, Langdon C, Opdyke BN (1999) Geochemical consequences of increased atmospheric carbon dioxide on coral reefs. Science 284:118-120

Kleypas J, Buddemeier R, Gattuso J-P (2001) The future of coral reefs in an age of global change. International Journal of Earth Sciences 90:426-437

Koop K, Booth D, Broadbernt A, Brodie J, Hoegh-Gulberg O, Capone D, Coll J (2001) ENCORE: The effect of nutrient enrichment on coral reefs, synthesis of results and conclusions. Mar Pollut Bull 42:91-120

Langdon C, Atkinson MJ (2005) Effect of elevated $\mathrm{pCO}_{2}$ on photosynthesis and calcification of corals and interactions with seasonal change in temperature/irradiance and nutrient enrichment. J Geophys Res 110(C9) [doi:10.1029/2004JC002576]

Manzello DP, Kleypas JA, Budd DA, Eakin CM, Glynn PW, Langdon C (2008) Poorly cemented coral reefs of the eastern tropical 
Pacific: possible insights into reef development in a high- $\mathrm{CO}_{2}$ world. Proc Natl Acad Sci U S A 105:10450-10455

Marshall AT, Clode P (2004) Calcification rate and the effect of temperature in a zooxanthellate and an azooxanthellate scleractinian reef coral. Coral Reefs 23:218-224

Marubini F, Barnett H, Langdon C, Atkinson MJ (2001) Dependence of calcification on light and carbonate ion concentration for the hermatypic coral Porites compressa. Mar Ecol Prog Ser 220:153-162

Mass T, Genin A, Shavit U, Grinstein M, Tchernov D (2010) From the cover: Flow enhances photosynthesis in marine benthic autotrophs by increasing the efflux of oxygen from the organism to the water. Proc Natl Acad Sci U S A 107:2527-2531

Mehrbach C, Culberson CH, Hawley JE, Pytkowicz RM (1973) Measurement of the apparent dissociation constant of carbonic acid in seawater at atmospheric pressure. Limnol Oceanogr 18:897-907

Moya A, Tambutte S, Tambutte E, Zoccola D, Caminiti N, Allemand D (2006) Study of calcification during a daily cycle of the coral Stylophora pistillata: Implications for light-enhanced calcification. J Exp Biol 209:3413-3419

Pandolfi JM, Connolly SR, Marshall DJ, Cohen AL (2011) The future of coral reefs response. Science 334:1495-1496

Price NN, Martz TR, Brainard RE, Smith JE (2012) Diel variability in seawater $\mathrm{pH}$ relates to calcification and benthic community structure on coral reefs. PLoS One 7:e43843

Reynaud S, Gattuso J-P, Cuif J-P, Jaubert J, Juillet-Leclerc A (1999) A novel culture technique for scleractinian corals: Application to investigate changes in skeletal delta $\mathrm{O}-18$ as a function of temperature. Mar Ecol Prog Ser 180:121-130

Reynaud S, Hemming NG, Juillet-Leclerc A, Gattuso JP (2004) Effect of $\mathrm{pCO}_{2}$ and temperature on the boron isotopic composition of the zooxanthellate coral Acropora sp. Coral Reefs 23:539-546

Schneider K, Erez J (2006) The effect of carbonate chemistry on calcification and photosynthesis in the hermatypic coral Acropora eurystoma. Limnol Oceanogr 51:1284-1293

Shamberger KEF, Feely RA, Sabine CL, Atkinson MJ, DeCarlo EH, Mackenzie FT, Drupp PS, Butterfield DA (2011) Calcification and organic production on a Hawaiian coral reef. Mar Chem 127:64-75
Shaw EC, McNeil BI, Tilbrook B (2012) Impacts of ocean acidification in naturally variable coral reef flat ecosystems. J Geophys Res 117 [doi: 10.1029/2011JC007655]

Silverman J, Lazar B, Cao L, Caldeira K (2009) Coral reefs may start dissolving when atmospheric $\mathrm{CO}_{2}$ doubles. Geophys Res Lett 36 [doi: 10.1029/2009GL036282]

Silverman J, Lazar B, Erez J (2007) Effect of aragonite saturation, temperature, and nutrients on the community calcification rate of a coral reef. J Geophys Res 112 [doi:10.1029/2006JC003770]

Suggett DJ, Dong LF, Lawson T, Lawrenz E, Torres L, Smith DJ (2012) Light availability determines susceptibility of reef building corals to ocean acidification. Coral Reefs 32:327-337

Suzuki A, Nakamori T, Kayanne H (1995) The mechanism of production enhancement in coral reef carbonate systems: Model and empirical results. Sediment Geol 99:259-280

Suzuki A, Kawahata H (2003) Carbon budget of coral reef systems: an overview of observations in fringing reefs, barrier reefs and atolls in the Indo-Pacific regions. Tellus B Chem Phys Meteorol 55:428-444

Tambutte E, Tambutte S, Segonds N, Zoccola D, Venn A, Erez J, Allemand D (2011) Calcein labelling and electrophysiology: Insights on coral tissue permeability and calcification. Proc R Soc Lond B Biol Sci 279:19-27

Vaughan TW, Wells JW (1943) Revision of the suborders, families and genera of the scleractinia. GSA Special Papers 44:363

Venti A, Kadko D, Andersson AJ, Langdon C, Bates NR (2012) A multi-tracer model approach to estimate reef water residence times. Limnol Oceanogr Methods 10:1078-1095

Watanabe A, Kayanne H, Hata H, Kudo S, Nozaki K, Kato K, Negishi A, Ikeda Y, Yamano H (2006) Analysis of the seawater $\mathrm{CO}_{2}$ system in the barrier reef-lagoon system of Palau using total alkalinity-dissolved inorganic carbon diagrams. Limnol Oceanogr 51:1614-1628

Yates KK, Halley RB (2003) Measuring coral reef community metabolism using new benthic chamber technology. Coral Reefs 22:247-255

Yates KK, Halley $\mathrm{RB}$ (2006) $\mathrm{CO}_{3}{ }^{2-}$ concentration and $\mathrm{pCO}_{2}$ thresholds for calcification and dissolution on the Molokai reef flat, Hawaii. Biogeosci 3:357-369 